University of Chicago Law School

Chicago Unbound

Journal Articles

Faculty Scholarship

2017

\title{
What Legal Authority Does the Fed Need During a Financial Crisis?
}

Eric A. Posner

Follow this and additional works at: https://chicagounbound.uchicago.edu/journal_articles

Part of the Law Commons

\section{Recommended Citation}

Eric Posner, "What Legal Authority Does the Fed Need During a Financial Crisis?," 101 Minnesota Law Review 1529 (2017).

This Article is brought to you for free and open access by the Faculty Scholarship at Chicago Unbound. It has been accepted for inclusion in Journal Articles by an authorized administrator of Chicago Unbound. For more information, please contact unbound@law.uchicago.edu. 
Essay

\section{What Legal Authority Does the Fed Need During a Financial Crisis?}

\section{Eric A. Posner ${ }^{\dagger}$}

During the financial crisis of 2007-08, the government sought to use aggressive measures to unfreeze the credit markets, but it found itself repeatedly blocked by the law. Officials reacted to their legal problems in different ways. During the collapse of Lehman Brothers, the Federal Reserve (Fed) refused to issue an emergency loan because of legal hurdles. However, in the cases of Bear Stearns and AIG, the Fed violated the law, or interpreted it in an extremely narrow way, rather than refraining from the emergency actions that events called for. The Fed and the Department of the Treasury relied on additional questionable legal interpretations for the numerous credit facilities that they established, and in the bailouts of Fannie Mae, Freddie Mac, General Motors, and Chrysler. In many cases, the agencies evaded the law by engaging in elaborate legal maneuvers that obfuscated their actions. When the Fed and Treasury sought additional legal authority from Congress, Congress initially refused, causing one of the most dangerous moments during the crisis.

At the same time, the mainstream view is that most of the government's actions were good policy. They put an end to a massive liquidity crisis - the worst since the Great Depression, possibly the worst in U.S. history-and spared the country an even more severe downturn than the Great Recession of 2007-

$\dagger \quad$ Kirkland \& Ellis Distinguished Service Professor and Arthur and Esther Kane Research Chair, University of Chicago Law School. Thanks to Anil Kashyap, Arvind Krishnamurthy, and participants at workshops at the University of Chicago Law School and Booth School of Business for comments, to Ethel Amponsah and Hannah Waldman for research assistance, and to the Russell Baker Scholars Fund for financial support. Copyright @ 2017 by Eric A. Posner. 
09. Moreover, the failure to rescue Lehman-law or no lawwas the Fed's biggest mistake: the collapse of Lehman introduced the most acute phase of the financial crisis, which until that point seemed manageable. The mismatch between law and policy raises numerous questions. Should the law be updated to permit the policy interventions that the government felt it needed to use? If so, how exactly should the law be changed?

It is possible to argue that the law makes little difference. The agencies and their leaders did not pay a price for their legal violations during the crisis; next time around, they may disregard the law again. ${ }^{1}$ But it is clearly better if the Fed acts lawfully than if it acts illegally. The legal restrictions were not costless. They caused the Fed to act more cautiously than it should have, and they have allowed officials to blame their failure to rescue Lehman in September 2008 on legal constraints, thereby deflecting criticism of their judgment. The law also forced the Fed and Treasury to structure straightforward transactions-loans and asset purchases-in complex ways, which reduced transparency, increased cost, and produced unintended consequences. The law was also responsible for the division of authority between different agencies-the Fed, Treasury, Federal Deposit Insurance Corporation (FDIC), the Securities and Exchange Commission (SEC), and others-and their disagreements during the crisis led to delay and coordination failures. Finally, the government's legal violations have generated expensive and time-consuming litigation, which may ultimately force the government to pay tens of billions of dollars to shareholders. ${ }^{2}$

In this Essay, I describe how the law needs to be updated in order to provide government agencies with the legal authority they need to resolve a financial crisis. I begin in Part I with a description of the Lender of Last Resort (LLR) function. It has been understood since the nineteenth century that central

1. See Eric A. Posner \& Adrian Vermeule, The Executive Unbound: AFTER THE MADISONIAN REPUBLIC 50 (2010) (discussing Congress's inability and unwillingness to curb the power of the Fed and Treasury in the wake of the financial crisis); $c f$. PHILIP A. WALLACH, TO THE EDGE: LEGALITY, LEGITIMACY, AND THE RESPONSES TO THE 2008 FINANCIAL CRISIS 160, 175-76 (2015) (arguing that the Fed's major constraint was that of maintaining legitimacy rather than legality, though the two were related).

2. See generally David Zaring, Litigating the Financial Crisis, 100 VA. L. REV. 1405 (2014) (discussing lawsuits brought by the government against financial institutions, as well as possible legal exposure of the government). 
banks must intervene during a financial crisis by making emergency loans to financial institutions, and possibly the broader market as well. This understanding was embodied in law in the Federal Reserve Act of 1913, which authorizes the Fed to make emergency loans during a financial crisis. ${ }^{3}$

However, the statute, while broadly worded, contains a number of restrictions that would impede the response to the financial crisis in 2007-09. Moreover, the complex regulatory regime gave certain crisis-related authorities to institutions other than the Fed, including FDIC, the SEC, and Treasury. Meanwhile, the financial system has changed enormously from 1913 to today, with many of the crucial changes taking place only over the last twenty years, in ways that were not adequately understood, even by experts, until the financial crisis exposed the fissures that those changes created. ${ }^{4}$ The Fed's focus has always been on the banking system, whose traditional function was to convert short-term lending into long-term lending. That function was partially taken over by the "shadow banking" system toward the end of the twentieth centurywhich consists of investment banks, insurance companies, and other non-bank financial institutions. It was in the shadow banking system that the financial crisis originated, and the mismatch between the law and the response to the crisis reflected in part the law's focus on the banking system.

Part II summarizes the consequences of the mismatch. As the crisis unfolded, policymakers realized that they needed to engage in numerous actions that did not fall comfortably within the confines of the law. The law authorized secured loans, ${ }^{5}$ but the crisis required the government to issue loans that could not be fully secured; to buy assets; and to acquire equity. ${ }^{6}$ Underlying the law was a crucial principle, which guided the Fed's conduct: the Fed should not engage in "fiscal" activities. This means that the Fed should make loans only when it is confident it could be repaid; it should not enter transactions that

3. Federal Reserve Act, 38 Stat. 263 (1913) (codified as amended at 12 U.S.C. $\S \S 221-522(2012))$.

4. For a discussion on the rise of "shadow banking," see GARY B. Gorton, Misunderstanding Financial Crises: Why We Don’t See Them COMING 125-33 (2012).

5. 12 U.S.C. $\S 343$ (2006). This section of the Federal Reserve Act has since been amended. See infra Part III.C.

6. See infra Part II.B. 
could cause a loss borne by taxpayers. As I will argue, this principle, as well as the law itself, significantly hampered the Fed's response.

Part III draws out implications for the law and for administrative structure. I argue that the LLR needs more powers than it currently has-including the power to make unsecured loans and buy assets, including equity; to take predictable losses; to seize control of financial institutions; and to regulate market transactions. I also argue that the LLR function should be centralized in a single, independent agency — most plausibly, the Fed itself. The LLR needs maximal power over the financial system because of the inherent unpredictability of crises. The next crisis will not look like the last one; the LLR needs to be able to do more than fight the last war. Unfortunately, in the Dodd-Frank Act, ${ }^{7}$ Congress moved in the opposite direction, weakening rather than strengthening the LLR.

A number of commentators argue that the financial crisis was caused by government meddling and was exacerbated by the market's belief that the government would bail out firms that failed. ${ }^{8}$ These commentators argue that the Fed's LLR function should be restricted or eliminated. ${ }^{9}$ While I disagree with this view, it is not my purpose to criticize it. Instead, my goal is to assume that the mainstream view is correct that the Fed acted properly during the financial crisis by lending widely, and to examine what reforms are necessary to supply it with the proper legal authority.

\section{BACKGROUND ON THE LLR}

\section{A. LIQUIDITY CRISES}

The principles governing the LLR were famously articulated by the British journalist Walter Bagehot in his book, Lombard Street, published in $1873 .{ }^{10}$ Although Bagehot was not the

7. Dodd-Frank Wall Street Reform and Consumer Protection Act, Pub. L. No. 111-203, 124 Stat. 1376 (2010).

8. See, e.g., John B. Taylor, The Financial Crisis and the Policy Responses: An Empirical Analysis of What Went Wrong (Nat'l Bureau of Econ. Research, Working Paper No. 14631, 2009), http://www.nber.org/papers/w1463 .pdf.

9. See, e.g., George Selgin, The Courage To Refuse, ALT-M (Oct. 31, 2015), http://www.alt-m.org/2015/10/31/courage-to-refuse.

10. WALter Bagehot, LOMBARD StREeT: A DESCRIPTION OF THE MONEY 
first person to identify these principles, he is routinely cited by central bankers, and we will do the same. ${ }^{11}$ According to Bagehot, during a liquidity crisis, the central bank should (1) lend as widely as possible; (2) against good collateral; and (3) at a high rate of interest. ${ }^{12}$

A liquidity crisis occurs when banks and other lenders stop (or greatly reduce) lending to other firms, even though those firms are solvent and would normally have no trouble repaying loans. Up until the financial crisis of 2007-09, a liquidity crisis would normally start with a bank run or panic. In a bank run, depositors withdraw money from a bank because they worry that the bank is insolvent and will not have funds to pay them in the future. As depositors withdraw money, the bank needs to raise cash by selling its assets, including illiquid assets that it must sell at a discount-at fire-sale prices. Because the bank receives less for the assets than their fundamental value, the bank can be driven into actual insolvency, even if it was not insolvent before. The crucial troubling feature of a classic bank run is that a bank that may well be solvent is driven into insolvency, because those who are skeptical about its solvency withdraw their money in a rush, destroying the bank; even people who believe the bank is solvent may withdraw their money in anticipation of the skeptics withdrawing their money. ${ }^{13}$

A run on a single bank can spread rapidly to other banks. This contagion can occur along many pathways. Banks lend money to each other in order to facilitate check-clearing and other aspects of the payment system, and to obtain interest on funds that are not currently needed for customers. If one bank fails, then it cannot repay other banks that have deposits with it, which can cause the failure of those other banks as well. Another pathway occurs through fire sales. If a run forces one bank to sell its home mortgage loans in fire sales, then the price of home mortgage loans will decline. This means that other banks that own home mortgage loans may suffer losses,

MARKET (1873).

11. Credit for originating the principles is usually also given to Henry Thornton, a British banker and politician, who died in 1815. See C.A.E. Goodhart, The Changing Role of Central Banks, 18 FIN. HIST. REV. 135, 136 (2011).

12. BAGEHOT, supra note 10, at 196-97.

13. For the classic analysis, see generally Douglas W. Diamond \& Philip H. Dybvig, Bank Runs, Deposit Insurance, and Liquidity, 91 J. PoL. ECON. 401 (1983) (providing a model of a bank run). 
alarming depositors who withdraw funds; this in turn forces the bank to sell additional mortgage loans in order to raise cash, driving the price down even further, in a downward spiral. Numerous well-managed banks with mortgage loans on their books may be driven into insolvency.

The essential feature of a liquidity crisis is that solvent banks become insolvent not because of bad loans or investments, but because of the withdrawal of liquidity. The withdrawal of liquidity could be driven by misunderstanding as in our example, but also by random events and economic conditions that cause people to start hoarding cash. The ultimate source of this fragility is the role of banks as financial intermediators. They obtain most of their funds from shortterm loans (deposits, which can be withdrawn at any time), and then lend those funds for long periods, like the thirty years of a typical home mortgage. The business model of banks assumes that depositors will, on average, keep most of their funds in the bank, and that as some customers withdraw their funds, those funds are replaced by deposits by other customers, so that the bank has a permanent pool of funds that it can lend out for a long term. If a run occurs, this model is undermined.

As we learned during the financial crisis of 2007-09, runs can originate outside the banking system. For example, in the repo market, a firm like an investment bank or hedge fund raises capital by selling securities to another firm-such as a pension fund or insurance company-and promising to buy them back at a slightly higher price in a day or two. The transaction is functionally identical to a secured loan-the seller obtains funds and then pays them back, with the securities serving as collateral. The two parties typically roll over the loan for long periods, with the result that the transaction approximates a demand deposit. At the onset of the crisis, mortgage-backed securities (MBSs) and other mortgage-derived securities served as collateral in many of these transactions. ${ }^{14}$ As mortgage default rates rose, the MBSs traded at lower prices, and firms lost confidence in their ability to value them accurately. The lenders in the repo market responded by imposing larger "haircuts"

14. Mortgage-backed securities (MSBs) are bonds that are secured by mortgages. I use the more general term "mortgage-derived securities" to encompass MBSs and other securities whose value is related to mortgage payment and default rates, including collateralized debt obligations (CDOs), which involve a more complicated transactional structure. 
on the collateral-meaning that the borrowers were required to supply additional MBSs in order to continue borrowing. ${ }^{15}$ When borrowers ran out of collateral, they sold off assets at fire-sale prices and were driven into insolvency. ${ }^{16}$

Financial economists are divided as to whether financial panics are caused by pure liquidity problems-solvent firms that cannot borrow-or also require insolvency. ${ }^{17}$ It is, of course, possible for a financial crisis to start because banks have made bad loans. If the loans are not repaid, a bank can become insolvent, causing a run as depositors rush to remove their funds, and harming other banks and other lenders. The Savings and Loan (S\&L) Crisis of the 1980s was probably due to such bad loans. Because high interest rates increased the cost of funds for S\&Ls, they were driven to make riskier loans for which they could charge high rates themselves. ${ }^{18}$ Deregulation allowed them to branch into areas of lending in which they had little experience. Overinvestment in commercial building created a price bubble, which destroyed the S\&Ls when it burst.

Most financial crises are likely a combination of liquidity and solvency problems. In the 2007-08 crisis, for example, many financial institutions failed simply because they issued too many subprime mortgages that defaulted and bought too many mortgage-related securities, which lost value because of those defaults. ${ }^{19}$ These firms were highly leveraged and overexposed to the real estate market. The defaults indicated that the fundamental value of the assets was very low, in aggregate lower than the value of the firms' liabilities. These firms were economically insolvent. However, many of the firms that suffered from withdrawal of credit were well managed, not excessively leveraged, and not excessively exposed to real estate. Lenders stopped lending to them because the lenders needed to hoard cash in order to protect themselves from runs, not because the lenders believed that the firms were insolvent. While

15. See GorTON, supra note 4 , at 191 .

16. See id. at 192; see also Arvind Krishnamurthy et al., Sizing Up Repo 50-51 (Nat'l Bureau of Econ. Research, Working Paper No. 17768, 2012).

17. For an evaluation of competing theories, see Itay Goldstein \& Assaf Razin, Three Branches of Theories of Financial Crises (Nat'l Bureau of Econ. Research, Working Paper No. 18670, 2013).

18. See LAWRence J. White, The S\&L Debacle: Public Policy Lessons FOR BANK AND THRIFT REGULATION 67-72 (1991).

19. See supra notes $14-16$ and accompanying text. 
the temporary decline in the market price of the assets caused by the withdrawal of liquidity made the firms appear insolvent, they were solvent in the fundamental-value or economic sense.

Financial crises are extreme events. They can introduce political turmoil and overthrow governments. The financial crisis of 2007-08 spawned the Tea Party and Occupy Wall Street, political polarization, and pervasive distrust of government. ${ }^{20}$ The immediate economic problem they cause is more complex. In principle, the failure of financial institutions could be selfcontained, producing no harm to anyone other than the shareholders, creditors, and employees of the firms that collapse. However, economists have shown that financial crises almost always lead to significant recessions. ${ }^{21}$ The leading explanation is that banks and other financial institutions add value through the relationships they develop with borrowers; when the lenders collapse, the relationship-specific information is lost. ${ }^{22}$ Another explanation is that the sudden withdrawal of credit from the "real" economy forces businesses to lay off workers, sell inventories at fire-sale prices, and so on, leading to further downward spirals that disrupt existing commercial relationships. ${ }^{23}$ The financial crisis of 2007-08 caused the Great Recession of 2007-09, in which all of these disruptions were visible.

\section{B. THE LLR's RESPONSE TO A LIQUIDITY CRISIS}

Conventional wisdom, as embodied in the Bagehot dictum, is that the LLR-typically, the central bank-should lend freely during a liquidity crisis against good collateral. ${ }^{24}$ The

20. See Atif Mian et al., Resolving Debt Overhang: Political Constraints in the Aftermath of Financial Crises 6, 23 (Nat'l Bureau of Econ. Research, Working Paper No. 17831, 2012).

21. See Carmen M. Reinhart \& Kenneth S. Rogoff, Growth in a Time of Debt, 100 AM. ECON. REv. 573, 573-74 (2010).

22. Ben S. Bernanke, Nonmonetary Effects of the Financial Crisis in the Propagation of the Great Depression, 73 AM. ECON. REV. 257, 263 (1983).

23. For discussions of these and other views, see Gary Gorton \& Andrew Winton, Financial Intermediation, in 1A HANDBOOK OF THE ECONOMICS OF FINANCE 431, 494-99 (George M. Constantinides et al. eds., 2003); Moritz Schularick \& Alan M. Taylor, Credit Booms Gone Bust: Monetary Policy, Leverage Cycles, and Financial Crises, 1870-2008, 102 AM. ECON. REV. 1029 (2012).

24. For a discussion and survey on emergency liquidity assistance (ELA), see generally Dietrich Domanski et al., Central Banks as Lenders of Last Resort: Experiences During the 2007-10 Crisis and Lessons for the Future (Fed. 
function of the LLR is to avoid bankruptcy-and sale of assets at fire-sale prices - of firms that are economically solvent. The LLR is not supposed to rescue insolvent firms, which should be wound down in bankruptcy and deserve to be liquidated because they were mismanaged, and are worth more in pieces than as going concerns.

The three elements of the Bagehot approach are thought to advance this goal. First, the LLR should lend freely, that is, to as many solvent firms as possible, because it needs to replace the withdrawal of credit from the economy by private creditors. The LLR should not limit itself to large or "too-big-to-fail" institutions, nor to banks. A liquidity crisis affects everyone and can lead everyone to sell off assets at fire-sale prices, which causes spiraling harm. The extension of credit by the LLR allows all firms to hold assets until maturity or until the credit market recovers. When fire sales stop and asset values recover, the crisis ends, and the LLR should withdraw credit.

Second, the LLR should lend against good collateral because it cannot afford to lose money. The meaning of good collateral is not entirely clear. In Bagehot's time, it may have meant government securities and other highly rated, liquid assets of the sort that a central bank routinely accepts as collateral during normal times. ${ }^{25}$ The Bank of England was a (mostly) private institution. ${ }^{26}$ If it loaned vast sums of money and then was not repaid, it would go bankrupt itself. While it was in the Bank of England's interest to rescue the financial system (so that it could continue lending), it was by definition not in its interest to risk its own existence. ${ }^{27}$ Modern central banks are public institutions, but this principle has been preserved under the theory that central banks should not take risks with taxpayers' money which is the domain of the fiscal authorityCongress and Treasury. Today, at a minimum, good collateral consists of assets whose "real" value (meaning value during ordinary times) exceeds the loan and is not excessively volatile. If central banks do not lend against good collateral, and are not

Reserve Bd., Working Paper No. 2014-110, 2014).

25. See Vincent Bignon et al., Bagehot for Beginners: The Making of the Lender-of-Last-Resort Operations in the Mid-Nineteenth Century, 65 ECON. HIST. REV. 580, 596-98 (2012).

26. See C.A.E. Goodhart, The CENTRAL BANK AND the FinAnCial SysTEM 334 (1995).

27. See id. at 333-35. 
paid back, the taxpayer must bear the loss. The good-collateral requirement just means that the credit risk incurred by the central bank should be as low as possible.

Third, the LLR should charge a "very high" rate of interest, or a "penalty" rate, in order to combat perverse incentive created by its own existence. LLR payoffs are a kind of insurance for financial institutions, and all types of insurance create moral hazard by protecting firms from downside risk. To combat moral hazard, the LLR charges a high interest rate, which means that the firm that receives an emergency loan is not fully insured but only partially insured, much as a person with homeowner or auto insurance must pay a deductible. ${ }^{28}$ Partial insurance in all these cases provides the insured entity with an incentive to take care ex ante. The penalty rate also encourages borrowers to return to the private market as soon as it recovers. It is important to understand that the penalty rate is not very high. It must be lower than the high rate of interest that prevails during the crisis; otherwise, it will not solve the liquidity crisis. Typically, a penalty rate might be just a percentage point or so higher than the rate that existed just prior to the crisis. $^{29}$

However, while central bankers continue to cite Bagehot, the principles have evolved to meet modern requirements. First, central banks typically focus on the banking system rather than financial institutions generally. In the United States, it was thought-until the crisis-that banks played the most important role in financial intermediation as well as in the payments system. Though other firms could be allowed to fail; banks could not. This idea was embodied in the Federal Reserve Act, which authorizes the Fed to lend to banks largely as a matter of discretion, while permitting it to lend to non-banks only in exigent circumstances and subject to various procedural and substantive constraints. ${ }^{30}$ This principle hampered the Fed's response to the financial crisis in its early stages. While

28. See Domanski et al., supra note 24 , at 4-5.

29. Under the Fed's current regulations, the penalty rate is fifty basis points above the market interest rate. See Credit and Liquidity Programs and the Balance Sheet, BOARD GOVERNORS FED. RES. SYS., https://www .federalreserve.gov/monetarypolicy/bst_lendingdepository.htm (last updated Feb. 23, 2017).

30. See 12 U.S.C. § 343 (2012); see also infra Part II.A (explaining the Federal Reserve Act). 
the Fed did eventually extend emergency loans to non-banks, it initially did so slowly and grudgingly. ${ }^{31}$

Second, central banks have found themselves hampered in determining whether collateral is "good" or not. During a liquidity crisis, assets lose their value because of the withdrawal of liquidity but may retain fundamental value. This means that a firm that holds an asset until the crisis ends will be able to sell it for more than the market price during the crisis. In order to resolve a crisis, the central bank must calculate this "real" value-that is, the value of the discounted stream of payoffs until the maturity of the asset, on the assumption that the credit market will eventually revive. However, it is difficult to determine how much of the price decline is attributable to the liquidity shortage and how much is attributable to fundamental economic variables. Some financial economists are skeptical that the concept of "good collateral" exists in the sense that Bagehot meant. For example, during the 2007-09 crisis, AAA collateralized debt obligations (CDOs) from the 2005 vintage (which mostly did not include subprime mortgages) lost considerable value - as much as seventy or eighty percent-and today are trading about five to ten percent below value. ${ }^{32}$ This suggests that a part of the crisis-era price decline could be attributed to fundamental problems, that is, defaults that were unanticipated at the time the CDOs were constructed. The Fed ended up accepting collateral that could not be considered good under any definition. ${ }^{33}$

Third, central banks do not usually demand penalty rates during a financial crisis. ${ }^{34}$ The Fed followed this pattern in the 2007-08 crisis after briefly charging a modest penalty rate at the earliest stage. The problem with penalty rates is that the market interprets borrowing at a penalty rate as a signal of possible insolvency. A borrower will not pay above-market interest for a loan unless it is desperate; if it is desperate, it is likely to fail even with temporary liquidity support from the

31. See DAVID Wessel, In FED We TRUst 147-49 (2009).

32. Richard Stanton \& Nancy Wallace, Bear's Lair: Index Credit Default Swaps at the Subprime Mortgage Crisis, 24 REV. FIN. STUD. 3250, 3255 fig.1 (2011).

33. See infra Part II.B; infra note 100.

34. See Glenn Hoggarth \& Farouk Soussa, Crisis Management, Lender of Last Resort and the Changing Nature of the Banking Industry, in FINANCIAL STABILITY AND CENTRAL BANKS: A GLOBAL PERSPECTIVE 166, 174-75 (2001). 
central bank. Creditors in the private market will therefore stop lending to it. This problem is acute when the financial institution in question depends on short-term loans. Short-term lenders can easily withdraw their funds or refuse to roll over loans, and quickly move their funds to a healthier institution. In this way, a financial institution that takes out an emergency loan from the LLR signs its own death warrant. To avoid branding emergency borrowers with the stigma of possible insolvency, central banks try to encourage as many institutions as possible to borrow from them-and this is only possible if a low interest rate, rather than a penalty rate, is offered. When many financial institutions borrow from the central bank, no one is stigmatized, because the weakest of them can no longer be singled out.

Moreover, there is a great deal of controversy as to whether the availability of the LLR does, in fact, create moral hazard. ${ }^{35}$ Financial crises are rare and unpredictable events. It is far from obvious how a financial institution can protect itself from a financial crisis. A firm that makes reckless loans will not be rescued by the LLR unless it happens to fail at the same time that a crisis takes place; but because crises are rare, a firm can hardly depend on such luck. Moreover, no one anticipated the 2007-08 financial crisis; accordingly, no one could have deliberately made reckless loans with the expectation of being bailed out. The problem was not that firms thought they would be rescued and consequently behaved recklessly; it was that they did not anticipate a systemic failure, and so took no precautions against it. Finally, the most straightforward way of deterring moral hazard is not to deny firms rescue loans-which defeats the purpose of resolving a financial crisis-but to impose strict ex ante regulation. The Dodd-Frank Act did just this.

35. Compare Selgin, supra note 9 (arguing that moral hazard is important), with GORTON, supra note 4 (arguing that moral hazard is not important). For evidence from the crisis, see Lamont K. Black \& Lieu N. Hazelwood, The Effect of TARP on Bank Risk-Taking, 9 J. FIN. STABILITY 790 (2013) (finding evidence of moral hazard); Philip E. Strahan \& Basak Tanyeri, Once Burned, Twice Shy: Money Market Fund Responses to a Systemic Liquidity Shock, 50 J. FIN. QUANTITATIVE ANALYSIS 119 (2015) (finding evidence that bailouts did not increase moral hazard in money market mutual fund markets); Luis Brandao-Marques et al., International Evidence on Government Support and Risk Taking in the Banking Sector (Int'l Monetary Fund, Working Paper No. 13/94, 2013) (finding evidence of moral hazard).

36. Dodd-Frank Wall Street Reform and Consumer Protection Act, Pub. L. No. 111-203, 124 Stat. 1376 (2010). 


\section{THE LAW}

While the Fed is usually identified as the LLR in the United States, the LLR function is actually shared by the Fed and FDIC. Before the Dodd-Frank Act, the Fed was understood to be the LLR for solvent banks and non-banks. FDIC was the LLR for insolvent banks. There was no LLR for insolvent nonbanks, which necessitated creative actions by the Fed and FDIC during the 2007-09 financial crisis, and the enactment of Economic Emergency Stabilization Act (EESA) in October 2008. ${ }^{37}$ The Dodd-Frank Act corrected this omission by providing for an orderly resolution process for insolvent financial institutions of all types. ${ }^{38}$

The Fed's authority to make emergency loans to banks is located in $\S 10 \mathrm{~B}$ of the Federal Reserve Act. ${ }^{39}$ The Fed can make short-term loans; the loans must be secured by high-quality collateral; and various procedural requirements and limits must be respected, especially if the bank is undercapitalized. Under current regulations, the Fed charges a penalty of fifty basis points above the federal funds rate for banks in "generally sound financial condition," and an additional fifty basis points for weaker banks. ${ }^{40}$ This type of lending is known as discountwindow lending. ${ }^{41}$

The Fed may make loans to non-banks under $\S 13(3) .^{42}$ This section requires the Fed to jump some significant procedural hurdles. The Fed must determine that "unusual and exigent circumstances" exist, and the Board of Governors must hold a vote with approval of a supermajority of five members. ${ }^{43}$ The loan must be "secured to the satisfaction of the Federal reserve bank," and the borrowers must be "unable to secure adequate credit accommodations from other banking institutions. ${ }^{, 44}$ DoddFrank added an additional requirement that loans be made

37. Pub. L. No. 110-343, 122 Stat. 3765 (2008) (codified at 12 U.S.C. $\S \S 5201-5202,5211-5241$ (2012)).

38. See infra Part III.C.

39. 12 U.S.C. $\$ 347 b$ (2012). 29.

40. See Credit and Liquidity Programs and the Balance Sheet, supra note

41. Id.

42. 12 U.S.C. $\S 343(3)(A)(2012)$.

43. See id.

44. Id. 
through a "program or facility with broad-based eligibility," meaning that the Fed must set out in advance eligibility requirements rather than pick and choose among borrowers.

Together, these two sections were thought to implement Bagehot's dictum. The Fed can lend broadly-to banks and non-banks-in an emergency, and must be fully secured. The statutes leave the Fed discretion as to how much to charge, allowing the Fed to charge a penalty rate if it desires.

FDIC is given the power to wind down banks that are undercapitalized or have failed. In normal cases, FDIC pays off insured depositors from its insurance fund, but otherwise creditors are not protected, and share in the proceeds of the sale of the bank's assets according to priority, and pro rata, as in a normal bankruptcy. In such cases, FDIC is required to minimize the cost to the insurance fund-which means paying only those creditors (mainly, depositors) covered by it. ${ }^{46}$ However, the law makes an exception where a bank's failure "would have serious adverse effects on economic conditions or financial stability." ${ }^{47}$ With the concurrence of the Secretary of the Treasury, a two-thirds majority of the Federal Reserve Board, and a twothirds majority of the FDIC Board of Directors, FDIC may pay off creditors of the bank in question. ${ }^{48}$ FDIC's role as LLR thus has two components: the routine payoff of insured bank depositors, and the power to compensate other bank creditors in emergency circumstances.

This leaves a significant gap, namely, for the large nonbank financial institution that faces solvency (rather than merely liquidity) problems. Before Dodd-Frank, FDIC had no jurisdiction over non-banks, while the Fed could lend to them only if they had collateral. During the crisis, the Fed and FDIC engaged in significant legal maneuvering in order to address this type of institution, as we will now discuss.

45. Dodd-Frank Wall Street Reform and Consumer Protection Act, Pub. L. No. 111-203, 124 Stat. 1376, 2113 (2010).

46. 12 U.S.C. $\S 1821(\mathrm{f})(2012)$.

47. Id. $\S 1823(\mathrm{c})(4)(\mathrm{G})$.

48. Id. 


\section{THE FED'S STRUGGLES WITH THE LAW DURING THE FINANCIAL CRISIS}

The financial crisis is usually dated to the summer of 2007, when the London Interbank Offered Rate (LIBOR) and Overnight Indexed Swap (OIS) spread-a measure of the cost of short-term unsecured lending among large banks-spiked. ${ }^{49}$ Until that time, the spread had remained very low, indicating that large banks trusted each other enough to lend to one another at barely above the Federal Funds rate. On August 9, 2007, BNP Paribas, a French bank, froze redemptions from three investment funds that held subprime mortgage-related assets which could no longer be valued. ${ }^{50}$ The LIBOR-OIS spread remained elevated through the end of 2007 and the first eight months of 2008. The crisis entered its acute phase after the collapse of Lehman on September 15, 2008. The government's most aggressive interventions took place during the remaining months of 2008 and the first six months of $2009 .^{51} \mathrm{In}$ the summer of 2009, the LIBOR-OIS spread returned to its historical level, indicating that the crisis was over.

\section{A. ACTING Within ITs AUTHORITY}

The Fed's initial responses to the financial crisis occurred after the BNP Paribas announcement, and in this initial phase, the Fed used traditional instruments that were well within its statutory powers. On August 17, 2007, the Fed lowered the interest rate for discount-window loans and extended the term of those loans. ${ }^{52}$ The Fed's authority to make loans to banks that are temporarily in need of liquidity is codified in $\S 10 \mathrm{~B}$ of the

49. Markus K. Brunnermeier, Deciphering the Liquidity and Credit Crunch 2007-2008, 23 J. ECON. PERSP. 77, 85-86 (2009).

50. Jason Hsu \& Max Moroz, Shadow Banks and the Financial Crisis of 2007-2008, in THE BANKING CRISIS HANDBOOK 39, 49-50 (Greg N. Gregoriou ed., 2010).

51. There are many narratives of the government's response to the financial crisis, including popular books and academic works. See, e.g., ALAN S. BLINDER, AFTER THE MUSIC STOPPED (2013); WESSEL, supra note 31; Randall S. Kroszner \& William Melick, The Response of the Federal Reserve to the Recent Banking and Financial Crisis (Dec. 2009) (unpublished manuscript) (on file with the University of Chicago Library).

52. Press Release, Bd. Governors Fed. Reserve Sys., For Immediate Release (Aug. 17, 2007), http://www.federalreserve.gov/newsevents/press/ monetary/20070817a.htm. 
Federal Reserve Act. ${ }^{53}$ In September of 2007, the Fed lowered its target federal funds rate from $5.25 \%$ to $4.75 \% .{ }^{54}$ It would continue lowering the interest rate during the crisis, reaching zero percent in December $2008 .^{55}$ The Fed's authority to adjust the target federal funds rate by trading securities on the open market is codified in $\S 14$ of the Federal Reserve Act. ${ }^{56}$ No one questioned the Fed's legal authority to engage in these actions. ${ }^{57}$

However, these actions were insufficient. Banks are reluctant to borrow from the discount window because of stigma. Although the loans are nominally secret, analysts and other market actors can discover whether banks took emergency loans simply by asking bank executives and inferring a "yes" if no answer is provided. ${ }^{58}$ The Fed sets the interest rate for emergency lending above the market rate in order to encourage banks, if possible, to use the market. But this means that a bank that takes an emergency loan from the Fed cannot obtain loans from the market, which indicates that it might fail at any time. As a result, potential investors and lenders may be reluctant to put money in the bank, hastening its demise. Nonetheless, the Fed made 26,395 loans from the discount window, totaling almost $\$ 11$ trillion, ${ }^{59}$ during the crisis (August 2007 to December 2009). ${ }^{60}$ In December 2007, the Fed tried to mitigate the stigma effect of discount-window lending by auctioning off

53. 12 U.S.C. $\S 347 \mathrm{~b}(\mathrm{a})$ (2012).

54. Press Release, Bd. Governors Fed. Reserve Sys., For Immediate Release (Sept. 18, 2007), https://www.federalreserve.gov/newsevents/press/ monetary/20070918a.htm.

55. Technically, the Fed targeted a range from $0 \%$ to $0.25 \%$. For data, see Effective Federal Funds Rate, ECON RES.: FED. RES. BANK ST. LOUIS, https:// research.stlouisfed.org/fred2/series/fedfunds (last visited Mar. 14, 2017).

56. 12 U.S.C. $\S 353$ (2012) (granting authority to purchase and sell cable transfers, acceptances, and bills).

57. The Fed's discount-window lending appears to have satisfied other legal requirements, including collateral requirements. See R. Alton Gilbert et al., Federal Reserve Lending to Troubled Banks During the Financial Crisis, 2007-2010, 94 FED. RES. BANK ST. LOUIS REV. 221, 221-42 (2012).

58. See Domanksi et al., supra note 24 , at $10-11$ (discussing the impediment of stigma in the 2008 financial crisis).

59. The vastness of this number is misleading. Many loans were very short term-for example, overnight. The Fed did not at any time lend out that much money in the aggregate.

60. Allen N. Berger et al., The Federal Reserve's Discount Window and TAF Programs: "Pushing on a String?" 38 tbl.1 (Jan. 2017) (unpublished manuscript) (on file with University of Chicago Library). 
the emergency loans rather than setting an arbitrarily high price for them. The Term Auction Facility (TAF), ${ }^{61}$ as the program was called, resulted in an additional 3937 loans, totaling $\$ 3.7$ trillion. ${ }^{62}$ While these programs did increase bank lending, ${ }^{63}$ they did not unfreeze the credit market. Indeed, major banks preferred to increase their liquidity by borrowing from Federal Home Loan Banks-whose emergency lending powers were apparently off the radar screen-and attracting insured deposits. ${ }^{64}$

The lowering of interest rates also failed to end the crisis. In theory, by lowering rates, the Fed reduces the cost of funds for banks and increases their incentive to lend. Home buyers can take advantage of low interest rates to obtain affordable mortgages, and existing homeowners can refinance their mortgages, providing them with additional cash to buys goods and services. However, the mechanism through which lower rates lead to greater lending had broken down. The financial crisis was caused by uncertainty about the value of mortgage-related assets owned by banks and other creditors. Banks and other financial institutions stopped lending because they could not determine the value of mortgage-related assets offered as collateral and the credit risk of borrowers that owned great quantities of mortgage-related assets. Fire sales of mortgage-related assets caused a collapse in their prices, which rendered many creditors insolvent based on market values, and so unable to lend, borrow, or raise capital. The modestly increased incentive, if any, to make loans encouraged by the interest rate cuts could not offset these massive risks. Moreover, as creditors realized that they could have trouble borrowing money, they hoarded cash rather than lent it out, so that they could repay their creditors or pay their expenses if further credit was not forthcoming. Home buyers and homeowners could not take advantage of low interest rates because creditors stopped lending. ${ }^{65}$

61. Press Release, U.S. Dep't of Treasury, Report to the Secretary of the Treasury from the Treasury Borrowing Advisory Committee of the Securities Industry and Financial Markets Association (July 30, 2008), https://www .treasury.gov/press-center/press-releases/Pages/hp1094.aspx.

62. Berger et al., supra note 60.

63. See id. at $4-5$.

64. See Adam Ashcraft et al., The Federal Home Loan Bank System: The Lender of Next-to-Last Resort?, 42 J. MONEY CREDIT \& BANKING 551, 552 (2010).

65. See GORTON, supra note 4 , at $186-94$. 
The more fundamental problem was that the source of the crisis lay outside traditional bank activities, in the shadow banking system. Most banks did not suffer from runs; deposit insurance and perhaps the discount window and related sources of support from the Fed reassured depositors that they would not lose their funds if banks failed. ${ }^{66}$ Runs occurred in the repo market, affecting investment banks, pensions, insurance companies, hedge funds, and other non-bank institutions; and against prime brokers-also usually investment bankswhich offered various credit-related services to their clients. These institutions could not access the discount window or TAF. They might have been helped indirectly by the reduction in interest rates if banks had been willing to lend to them, but banks were reluctant to lend to them because the banks could not be sure that the borrowers were solvent.

To address the problems in the shadow banking system, the Fed was forced to draw on its authority under $\S 13(3)$ of the Federal Reserve Act, which at the time (it has since been amended $^{67}$ ) allowed the Fed to make emergency loans to "individuals, partnerships, and corporations"-in other words, people and institutions other than banks - "in unusual and exigent circumstances." ${ }^{68}$ A supermajority of the members of the Board of Governors was needed to authorize these loans, and the loans must be "secured to the satisfaction of the Federal Reserve bank" that makes the loan. ${ }^{69}$ The Fed had not made a loan under $\S 13(3)$ since the Great Depression, and Fed officials were reluctant to use this law at first. ${ }^{70}$ But the law is the law, and many of the Fed's actions under $\S 13(3)$ were clearly lawful.

For example, on March 11, 2008, the Fed created the Term Securities Lending Facility (TSLF), through which the Fed loaned Treasury securities to primary dealers (major investment banks) that posted collateral. ${ }^{71}$ By this time, it was clear

66. See Sheila Bair, Bull By the Horns: Fighting To SAVE Main StREet FROM WALl STREET AND WALl STREeT FROM ITSElF 292-93 (2012) ("Because of the confidence of an FDIC guarantee, [banks] were awash with funds.").

67. The amendments are discussed infra Part III.C.

68. 12 U.S.C. $\$ 343(\mathrm{~A})(2012)$.

69. $I d$.

70. Ben S. Bernanke, The Courage To ACT: A MEMoIr of A CRISIS AND ITS AFTERMATH 205-06 (2015) (explaining the Federal Reserve's reluctance to use $\S 13(3)$ in the 2008 crisis).

71. Monetary Policy: Term Securities Lending Facility, BOARD GOVER- 
that "unusual and exigent circumstances" existed-a major collapse of the credit markets. The loans were made against collateral already used in the repo market, including investmentgrade corporate bonds and mortgage-backed securities. In the initial stages of the TSLF, the collateral was highly rated, almost certainly qualifying as "good collateral." ${ }^{72}$ On March 16, 2008, the Fed supplemented the TSLF with the Primary Dealer Credit Facility (PDCF), through which primary dealers could obtain short-term cash loans by posting the same types of collateral. ${ }^{73}$ The PDCF was also legally straightforward-although as we will discuss in the next section, some questions arise as to the quality of the collateral that the Fed accepted.

However, while firms borrowed huge sums through the TSLF and PDCF, the facilities failed to resolve the crisis. ${ }^{74}$ The rescue of Bear, also in March 2008, was probably a more important intervention at the time, since it indicated-or seemed to indicate-that the Fed would not allow a major financial institution to fail. As I will discuss below, the Bear rescue was legally questionable. By contrast, the TSLF and the PDCF were hardly used throughout the crisis other than during its acute phase in September 2008. Investment banks feared stigma in the same way that commercial banks feared the stigma of the discount window. The Fed's legal authorities were inadequate for resolving the crisis.

NORS FED. RES. SYS. (Feb. 5, 2010), http://www.federalreserve.gov/ monetarypolicy/tslf.htm.

72. The collateral used in the TSLF decreased in quality over time, raising the question whether the "good collateral" requirement was consistently satisfied. But, unlike the Primary Dealer Credit Facility (PDCF) collateral, the TSLF collateral never fell below investment grade. See Term Securities Lending Facility and TSLF Options Program, BOARD GOVERNORS FED. RES. SYS., http://www.federalreserve.gov/newsevents/files/tslf.xls (last visited Mar. 14, 2017).

73. See Regulatory Reform: Primary Dealer Credit Facility (PDCF), BOARD GOVERNORS FED. RES. SYS., http://www.federalreserve.gov/newsevents/ reform_pdcf.htm (last updated Feb. 12, 2016).

74. To review the data, see Regulatory Reform: Term Securities Lending Facility (TSLF) and TSLF Options Program (TOP), BOARD GOVERNORS FED. RES. SYS., http://www.federalreserve.gov/newsevents/reform_tslf.htm\#data (last updated Feb. 12, 2016). 


\section{B. StREtChing THE Limits OF ITS AUTHORITY AND Violating THE LAW}

In March 2007, a run began against Bear. Bear was a large investment bank and primary dealer, which borrowed heavily on the repo market. Its creditors lost confidence in Bear and refused to roll over the loans. ${ }^{75}$

Fearing a systemic failure, the Fed authorized a $\$ 12.9$ billion bridge loan to JP Morgan, which JP Morgan would then lend to Bear, using as collateral $\$ 13.8$ billion in securities owned by Bear. ${ }^{76}$ The loan was originally directed at JP Morgan so as to avoid having to rely on $\S 13(3)$. But this bit of legal legerdemain, crafted by the Federal Reserve Bank of New York's (FRBNY) general counsel, was nixed by the Federal Reserve Board's general counsel. ${ }^{77}$ The Fed ended up citing $\S 13(3)$. The loan bought time which Bear used to find a purchaser. Merger negotiations between JP Morgan and Bear commenced. In the final transaction, which was consummated on March 24, 2008, the Fed created a special purpose vehicle (SPV) called "Maiden Lane," which was financed from a $\$ 28.82$ billion loan from the Fed and a $\$ 1.15$ billion subordinated loan from JP Morgan. ${ }^{78}$ The Fed was given the "residual interest," ty, in the assets. Maiden Lane purchased toxic assets from Bear, including agency MBSs, commercial and residential loans, non-agency residential MBSs, and other derivatives.

Under these terms, JP Morgan and the Fed shared the downside. If the value of the assets declined up to $\$ 1.15$ billion, JP Morgan would absorb the entire loss; if it declined more, then the Fed would absorb the residual loss up to $\$ 28.82$ bil-

75. My account follows the U.S. Government Accountability Office's report. U.S. GOV'T ACCOUNTABILITY OFFICE, FEDERAL RESERVE SYSTEM: OPPORTUNITIES EXIST TO STRENGTHEN POLICIES AND PROCESSES FOR MANAGING EMERGENCY ASSISTANCE 22-26, 178-84 (2011), http://www.gao.gov/new.items/ d11696.pdf [hereinafter FEDERAL RESERVE REPORT].

76. The loan was routed through JP Morgan, but the Fed recognized that the loan was functionally a loan to Bear.

77. See BERNANKE, supra note 70, at 214.

78. Id. at 221-23.

79. Documents Relating to the Bailout of Bear Stearns, INTERNET ARCHIVE, https://archive.org/stream/DocumentsRelatingToTheBailoutOfBear Sterns_472/2009-164DocPt3_djvu.txt (last visited Mar. 14, 2017). See generally Maiden Lane Transactions, FED. RES. BANK N.Y., https://www.newyorkfed.org/ markets/maidenlane.html\#significanttransactionterms (last visited Mar. 14, 2017). 
lion. The Fed alone benefited from the upside. If the assets were sold for more than $\$ 30$ billion, then JP Morgan and the Fed would be paid off in full, and the Fed would receive the residual. As it turned out, the assets appreciated, and the Fed earned a profit.

The Fed invoked § 13(3) for this transaction with little explanation. The theory was apparently that the transaction was secured to the Fed's satisfaction, and that the loan was directed to a non-bank in unusual and exigent circumstances, as § 13(3) permitted. This argument could certainly be used to justify the initial bridge loan-assuming that Bear's collateral was actually adequate, for which there is no evidence one way or the other. ${ }^{80}$ However, the Maiden Lane transaction was less clearly lawful.

The Fed does not have the authority to buy assets other than Treasury securities and a few other types of assets used in open-market operations. ${ }^{81}$ If the Fed had simply purchased MBSs and the other toxic assets for $\$ 30$ billion, it would have violated the law. The transaction was structured to avoid this type of blatant illegality. Instead of buying assets, the Fed made a secured loan to Maiden Lane, which then paid the Fed back. A secured loan falls more comfortably into the Fed's $\S 13(3)$ authority.

The problem with this approach is that the transaction provided that the value of the Fed's interest would be tightly connected to the value of the underlying assets. If the assets fell in value by as little as four percent, the Fed would lose money. If the assets rose in value, the Fed would receive the entire gain. By contrast, in a secured loan-and especially a loan secured by "good" collateral, that is, high-quality collateral, in Bagehot's sense-the lender bears very little to no risk from the fluctuation of asset values. Functionally, the Maiden Lane transaction was a sale of assets, not a secured loan. ${ }^{82}$

80. The data set posted at the Federal Reserve discloses the type of collateral but uncharacteristically does not break it down by rating. See Bridge Loan to Bear Stearns through JP Morgan Chase, BOARD GOVERNORS FED. RES. SYS., http://www.federalreserve.gov/newsevents/files/blbs.xls (last visited Mar. 14, 2017). Oddly, the data set shows the collateral as of 2010 rather than when the loan was originated in March 2008.

81. 12 U.S.C. $\S 353$ (2012).

82. See Alexander Mehra, Legal Authority in Unusual and Exigent Circumstances: The Federal Reserve and the Financial Crisis, 13 U. PENN. J. BUS. L. 221, 236 (2011); Thomas Porter, The Federal Reserve's Catch-22: A Legal 
The PDCF itself raises legal questions. Section 13(3) allows the Fed to make secured loans but the loans must be "secured to the satisfaction" of the Fed. ${ }^{83}$ The PDCF accepted CCC and other low-rated collateral and indeed collateral that was not rated at all, including equity interests that were not traded and exceedingly difficult to value. ${ }^{84}$

The Fed might argue that "secured to [its] satisfaction" means that complete discretion is vested in the Fed. But if this were true, then the Fed could issue unsecured loans based on collateral with no value. The statute limits the Fed to secured loans, and the Fed must make a good-faith determination that the collateral adequately secures it. ${ }^{85}$ For example, the Fed would be justified in arguing that collateral trading at a low market value adequately secures it because crisis conditions suppress the price. But the Fed would not be justified in taking as collateral assets whose fundamental value is minimal. Because the Fed has not disclosed its analysis of the collateral, we do not know whether it acted lawfully or not, but we are not required to take its word for it, and the large quantity of unrated and low-rated assets that it accepted as collateral in the PDCF provides grounds for skepticism.

The Fed's rescue of AIG in September 2008 faced similar obstacles, forcing the Fed to evade the law yet again. It created two new SPVs-Maiden Lane II, which purchased MBSs and related assets from AIG's insurance subsidiaries; and Maiden Lane III, which purchased CDOs from AIG's counterparties. ${ }^{86}$ In both cases, the Fed shared the downside with AIG and was given a major share of the profits-that is, equity. These two transactions were legally dubious in the same way that the original Maiden Lane transaction was.

Another aspect of the AIG rescue was legally questionable. In the initial transaction, the Fed loaned $\$ 85$ billion to AIG secured by all its assets and, in addition to charging interest and

Analysis of the Federal Reserve's Emergency Powers, 13 N.C. BANKING INST. 483 (2009). But see WALLACH, supra note 1, at 53-54.

83. 12 U.S.C. $\$ 343(3)(\mathrm{A})(2012)$.

84. See Primary Dealer Credit Facility Data, BOARD GOVERNORS FED. RES. SYS., http://www.federalreserve.gov/newsevents/files/pdcf.xls (last visited Mar. 14, 2017).

85. 12 U.S.C. $\S 343(3)$.

86. See TIMOTHy F. GEITHNER, STRESS TEST: REFLECTIONS ON FINANCIAL CRISES 246 (2014). 
fees, the Fed took nearly eighty percent of AIG's equity. The equity was put into a trust whose beneficiary was the U.S. Treasury. A court later held that the transaction violated the law because $\S 13(3)$ does not give the Fed the authority to take equity in return for a loan. ${ }^{87}$

Later in the fall of 2008, the Fed opened additional credit facilities. To stop a run on money market mutual funds, the Fed opened the Asset-Backed Commercial Paper Money Market Mutual Fund Liquidity Facility (AMLF) and the Money Market Investor Funding Facility (MMIF). ${ }^{88}$ It also opened the Commercial Paper Funding Facility (CPFF) and the Term Asset-Backed Securities Loan Facility (TALF) ${ }^{89}$ All of these facilities formally made "loans," consistent with $\S 13(3)$ and the Fed's other authorities. But, other than TALF,${ }^{90}$ they all raised legal problems.

Through the AMLF, the Fed made nonrecourse loans to banks, which in turn used the money to buy asset-backed commercial paper from money market mutual funds. ${ }^{91}$ The banks used the asset-backed commercial paper as collateral for the Fed loans. Thus, formally the Fed made secured loans to banks, though, perhaps in recognition that the ultimate beneficiaries were non-banks, the Fed cited its $\S 13(3)$ authority. Functionally, the banks were used as conduits through which the Fed purchased the asset-backed commercial paper. If commercial paper dropped in value, the Fed would be left holding the collateral, with no recourse against the banks. So, just like in a sale, the Fed bore the risk of the decline of asset values. Unlike

87. Starr Int'l Co. v. United States, 121 Fed. Cl. 428, 466 (2015) (holding that the Fed's taking of equity ownership and voting control constituted an illegal exaction under the Fifth Amendment). Disclosure: I worked on this case for the plaintiff.

88. Regulatory Reform: Asset-Backed Commercial Paper Money Market Mutual Fund Liquidity Facility, BOARD GOVERNORS FED. RES. SYS., http:// www.federalreserve.gov/newsevents/reform_amlf.htm (last updated Feb. 12, 2016); Money Market Investor Funding Facility, BOARD GOVERNORS FED. RES. SYS., http://www.federalreserve.gov/monetarypolicy/mmiff.htm (last updated Feb. 5, 2010).

89. Regulatory Reform: Commercial Paper Funding Facility, BOARD GOVERNORS FED. RES. SYS., http://www.federalreserve.gov/newsevents/reform_cpff .htm (last updated Feb. 12, 2016).

90. Through TALF, the Fed effectively made loans to businesses, which were secured by various securities, consistent with $\S 13(3)$. See FEDERAL RESERVE REPORT, supra note 75 , at app. XII.

91. Id. at app. II, at 28-29. 
a sale, the Fed did not have a share of the upside, but would be required to return the collateral to the banks if they repaid the loans. The MMIF complemented the AMLF by enabling money market mutual funds to sell other types of short-term debt instruments, including unsecured commercial paper. ${ }^{92} \mathrm{~A}$ more complicated structure, involving SPVs, protected the Fed from more of the downside, but did not cure the legal infirmities.

In the case of the CPFF, the veil was dropped. The Fed set up a SPV called CPFF LC, which purchased commercial paper, both secured and unsecured, directly from issuers. ${ }^{93}$ The Fed funded CPFF LC with secured loans. Accordingly, the risk of any variation in asset values-up or down-would be borne by the Fed. This could be viewed simply as a purchase of assets (the commercial paper) or, indirectly, as an unsecured loan to the issuers, in either case the Fed was in violation of the law, which does not authorize asset purchases and requires all loans to be secured. ${ }^{94}$

The Fed's legal division made two arguments that the CPFF was lawful. ${ }^{95}$ First, it argued that the recipient of the loan was CPFF LC, and that the loan was secured by the commercial paper owned by CPFF LC. Accordingly, the transaction was a loan secured to the satisfaction of the Fed. However, this argument is specious as it would allow the Fed to make an unsecured loan to anyone simply by creating an SPV. Imagine, for example, that the Fed would like to make an unsecured loan to Joe Shmo, who has no assets. Following the legal division's advice, the Fed could create an SPV called Shmo LC. Shmo LC would then lend money to Joe, and in return receive an unsecured note from him, that is, an IOU. Shmo LC would get its money from the Fed, which would make a $\S 13(3)$ loan to Shmo LC secured by Shmo's note. Functionally, this is an unsecured loan to Shmo. If he defaults on the loan from Shmo LC, Shmo

92. Id. at app. X.

93. Id. at app. VII. 45.

94. See WALLACH, supra note 1, at 94-96; Mehra, supra note 82, at 244-

95. See Memorandum from Legal Division on Authority of the Federal Reserve To Provide Extensions of Credit in Connection with a Commercial Paper Funding Facility (CPFF) to File (Mar. 9, 2009), http://fcic-static.law .stanford.edu/cdn_media/fcic-docs/2009-03-09_Federal_Reserve_Bank_Letter_ from_Legal_Division_to_Files_Re_Authority_of_the_Federal_Reserve_to_ provide_extensions_of_credit_in_connection_with_a_commercial_paper_ funding_facility_CPFF.pdf. 
LC would have no money to repay the Fed, and the collateralShmo's note-would be worthless.

One could argue that the relevant language in § 13(3), "secured to the satisfaction of the Federal Reserve bank," just means that the Fed must jump through the legal hoops of filing notice of a security interest and can take a security interest in whatever it wants, such as the cash it advances to the borrower and the proceeds (if any) from the borrower's use of that cash. The Fed has never made this argument, as I far as I know. The reason is most likely that the Fed, Congress, and all other relevant actors have always understood $\S 13(3)$ to implement Bagehot, which requires "real" security-in the sense of collateral that would render the loan riskless or close to that, based on (good-faith) predictions of post-crisis collateral values. Note that if the Fed did believe that it could make unsecured loans, its claim that a Lehman rescue was illegal would be impossible to defend.

The Fed's legal division made a second argument in defense of the CPFF. It argued that that Fed could deem the loan "secured to [its] satisfaction" because in these cases the issuer was charged an "insurance fee" of 100 basis points. ${ }^{96}$ The insurance fee was in essence a premium, which, multiplied by the number of borrowers, created an "insurance fund" that could be used to pay the Fed if borrowers defaulted. ${ }^{97}$

This argument is also exceedingly questionable. The legal division simply redescribes an unsecured loan as a secured loan. To see why, note that every unsecured loan-in private markets as well as Fed loans-carries with it an interest rate that is higher than the interest rate of a secured loan, all else equal. This "premium" can be described as an insurance fee if you want: the point of it is to compensate the borrower for the extra risk that results from the absence of collateral. A private bank makes hundreds of unsecured loans; it can certainly claim, if the Fed's reasoning is correct, that the high interest rate is a "premium," and so goes into an "insurance fund" that can be used to compensate the bank if borrowers default. If this logic is accepted, every unsecured loan is actually a secured loan. Try telling that to your bank examiner (who may well be the Fed itself)!

96. Id. at 7 .

97. Id. at 7-8. 


\section{Prevented from TAKing Necessary ACtions}

Despite their elastic interpretations of the law, government officials-including Bernanke, Paulson, and Geithner-claimed that legal restrictions prevented the Fed from rescuing Lehman. ${ }^{98}$ They argue that Lehman, unlike Bear and other institutions, was insolvent, and accordingly could not be saved under $\S 13(3)$.

This claim has engendered great controversy. First, § 13(3) does not require that the borrower be solvent; it requires that loans be secured. Up until Lehman's bankruptcy, the Fed made loans to Lehman through the PDCF, including a $\$ 28$ billion loan on September 15, 2008. ${ }^{99}$ The loans were lawful because they were backed by Lehman's collateral. The Fed evidently felt that even highly dubious collateral-C-rated and unrated securities-could secure the PDCF loans. ${ }^{100}$ If the Fed was correct, it could have lawfully continued lending to Lehman, enabling the investment bank to pay off many of its counterparties. The Fed could also have purchased the securities using the SPV mechanism developed for the Bear rescue.

Moreover, the New York Times reported that lower-level officials in FRBNY believed that Lehman was solvent. ${ }^{101}$ A subsequent FDIC report found that Lehman was insolvent, but only barely. ${ }^{102}$ And a careful academic study finds that Lehman was economically solvent until the first week of September 2008, when it started unloading its assets at crisis-driven prices. ${ }^{103}$ While FRBNY might have believed that it would lose money on a loan to Lehman, it could certainly have extended credit for a long enough period to permit an orderly wind-down. Moreover,

98. See BERNANKE, supra note 70, at 258-65; GEITHNER, supra note 86, at 186; Henry M. PAUlson, ON THE BRINK: Inside THE RACE To StoP THE COLLAPSE OF THE GLOBAL FINANCIAL SYSTEM 182-86 (2010).

99. See Primary Dealer Credit Facility, BOARD GOVERNORS FED. RES. SYS., http://www.federalreserve.gov/newsevents/reform_pdcf.htm\#data (last updated Feb. 12, 2016). id.

100. The collateral descriptions are also available at the Fed's website. See

101. James B. Stewart \& Peter Eavis, Lehman Revisited: The Bailout That Never Was, N.Y. TIMES, Sep. 30, 2014, at A1.

102. The Orderly Liquidation of Lehman Brothers Holdings Inc. Under the Dodd-Frank Act, 5 FDIC Q., no. 2, 2011, at 1.

103. See Emily Kapur, The Next Lehman Bankruptcy, in MAKING FAILURE FEASIBLE: HOW BANKRUPTCY REFORM CAN END “TOO BIG TO FAIL" 175, 18799 (Kenneth E. Scott et al. eds., 2015). 
the Fed could very likely have made fully secured loans to Lehman earlier in 2008, before Lehman's assets lost value. Because a rescue at an earlier date would have made Lehman's fire sales unnecessary, Lehman would not have been driven into (or near) insolvency by those sales.

Second, contemporary evidence indicates that the major reasons for letting Lehman fail were political and operational rather than legal. Paulson wanted to avoid being labeled "Mr. Bailout"-for political, and possibly ideological reasons, he wanted to avoid another Bear-style bailout. Paulson and others also worried that a Lehman bailout would create moral hazard. ${ }^{104}$ At the same time, the Fed was prepared to provide financial assistance if Barclays agreed to purchase Lehman, as everyone hoped. ${ }^{105}$ It is hard to believe that Bernanke and the others would have facilitated a purchase if they believed that Lehman was deeply insolvent, since such a purchase would have damaged Barclays, one of the largest banks in the world and an even more important institution than Lehman. Finally, Bernanke seemed more concerned that the Fed would lose money on a bailout than that the bailout was illegal. As I will discuss below, a risky loan, even if legal, might have angered Congress and posed a threat to the Fed's independence.

All that said, the questionable legality of a Lehman rescue provided a convenient excuse to government officials whose economic, political, and operational judgments were under heavy scrutiny. Moreover, some combination of legal and political norms must have led Bernanke to advise Paulson in September that the Fed's limits had been reached, and that Congress must be approached. ${ }^{106}$ Bernanke may have believed that the financial crisis required the government to buy toxic assets, make equity investments in banks, make unsecured loans, and engage in other transactions that either the Fed could not engage in, or could engage in only to a limited extent. ${ }^{107}$ These considerations could have taken different forms. Perhaps marginal violations of the law were permissible, but wholesale violations were not. Or perhaps the Fed lacked the institutional capacity to rescue the entire financial system-it just did not

104. PAULSON, supra note 98 , at 109-10; see WESSEL, supra note 31 , at 174-75.

105. See WESSEL, supra note 31 , at 21.

106. See BERNANKE, supra note 70, at 299.

107. See id. 
have enough staff, experience, and resources. Or perhaps the Fed sought to force Congress to share the political blame for the unpopular bailouts.

Congress passed the Emergency Economic Stabilization Act on October 3, 2008. ${ }^{108}$ However, the legislative response was far from ideal. In its first attempt, the House of Representatives voted down the bill, with nearly catastrophic consequences for the financial system. ${ }^{109}$ The Dow Jones index fell eight percent. A later bill, overloaded with pork, did pass. There is little evidence that members of the House or Senate understood what was at stake; they deferred to the expertise of the agency heads. ${ }^{110}$ Hearings were expedited; witnesses who disagreed with the bills under considerations were not permitted to testify. ${ }^{111}$ Rather than resolve any of the policy debates, Congress gave enormous discretion to Treasury to spend hundreds of billions of dollars as it saw fit, subject to very loose supervision.

How can we summarize the relationship between the law and the Fed's actions? The overall picture is complex. The Fed arguably violated the law on several occasions, flagrantly violated it on a few occasions, but also acted as though the law put limits on what it could accomplish. In particular, the Fed felt constrained, on some (but not all) occasions, by legal prohibitions on asset purchases, equity investments, and unsecured lending.

\section{TREASURY}

The Fed was not the only government agency that violated the law during the financial crisis. Treasury and FDIC did as well.

During the run on money market mutual funds in September 2008, Treasury supplemented the Fed's rescue efforts by creating an insurance program for money market mutual funds. In return for a fee, a fund would receive a Treasury

108. Pub. L. No. 110-343, 122 Stat. 3765 (codified at 12 U.S.C. $\S 5201-$ $5261(2012))$.

109. See John Samples, Lawless Policy: TARP as Congressional Failure, 660 POL'Y ANALYSIS 1, 6-8 (2010).

110. See id. at $9-10$.

111. Charles W. Calomiris \& Urooj Khan, An Assessment of TARP Assistance to Financial Institutions, 29 J. ECON. PERSP. 53, 55 n.2 (2015); Samples, supra note 109 , at $4-9$. 
guarantee for its investors. ${ }^{112}$ The purpose of this program was to restore confidence in money market mutual funds. Treasury made available $\$ 50$ billion for this program from the Exchange Stabilization Fund (ESF). ${ }^{113}$

The ESF was created by Congress in 1934 for the purpose of stabilizing foreign exchange rates, as the name implies. ${ }^{114}$ The law empowered Treasury to do so by giving it the authority to buy treasury securities, gold, foreign exchange, "and other instruments of credit and securities the Secretary considers necessary." means that if the Secretary believes that Treasury must purchase or sell some other security in order to maintain the value of the dollar in terms of gold or foreign currencies, it may do so.

As far as I know, neither Treasury nor anyone else has offered a legal argument that the use of ESF to guarantee money market mutual funds was lawful. Guaranteeing the funds was not designed to affect the value of the U.S. dollar. ${ }^{116}$ Guaranteeing funds is not the same thing as dealing in securities; nor is there any other language in the statute that implies power to guarantee money market mutual funds or any other institutions. Nothing in the law authorized Treasury to require premiums in return for the guarantee.

The government's lack of legal power to address the financial crisis led to the enactment of EESA ${ }^{117}$ This law put immense resources at Treasury's disposal, subject to exceptionally broad limits. Nonetheless, Treasury violated those limits. The statute authorizes it "to purchase . . . troubled assets from any financial institution." 118 "Troubled assets" are mortgages, mortgage-related securities, and "any other financial instrument

112. Press Release, U.S. Dep't of the Treasury, Treasury Announces Guaranty Program for Money Market Funds (Sept. 19, 2008), http://www.treasury .gov/press-center/press-releases/Pages/hp1147.aspx.

113. Id.

114. 31 U.S.C. $§ 5302(2012)$.

115. Id.

116. It is possible to argue that by rescuing money market funds, Treasury indirectly rescued European banks-which relied on funding from the money market mutual funds-and in this way prevented the euro from collapsing and hence the dollar from appreciating against the euro. But Treasury did not make this argument, no doubt because no one would have believed it.

117. Pub. L. No. 110-343, 122 Stat. 3765 (codified at 12 U.S.C. §§ 5201$5261(2012))$.

118. 12 U.S.C. $§ 5211(a)(1)$ (2012). 
that the Secretary ... determines the purchase of which is necessary to promote financial market stability." institution" "means any institution, including, but not limited to, any bank, savings association," etc.-with a list of other standard financial institutions. ${ }^{120}$

Treasury violated these limits in two programs. First, in the Homeowner Affordable Modification Program (HAMP), Treasury attempted to pay loan servicers, investors, and homeowner to renegotiate mortgages. ${ }^{121}$ Paying a loan servicer to renegotiate a loan is not the same thing as buying a financial instrument. Although the latter term is not defined in EESA, it can be found in other areas of the law. For example, the Uniform Commercial Code provides that:

"Instrument" means a negotiable instrument or any other writing that evidences a right to the payment of a monetary obligation, is not itself a security agreement or lease, and is of a type that in ordinary course of business is transferred by delivery with any necessary indorsement or assignment. The term does not include (i) investment property, (ii) letters of credit, or (iii) writings that evidence a right to payment arising out of the use of a credit or charge card or information contained on or for use with the card. ${ }^{122}$

Courts distill this definition into two elements: (1) a writing that evidences a right to the payment of a monetary obligation; (2) of a type that in ordinary course of business is transferred by delivery with any necessary endorsement or assignment.

119. Id. § 5202(9).

120. Id. § $5202(5)$.

121. See infra note 124 and accompanying text.

122. U.C.C. § 9-102(1)(47) (AM. LAW INST. \& UNIF. LAW COMM'N 2000). Similar definitions can be found in federal law. See, e.g., 18 U.S.C. § 514(a)(2) (2012); 26 U.S.C. § 731(c)(2)(C) (2012); see also United States v. Sargent, 504 F.3d 767, 770-71 (9th Cir. 2007) (stating that postage statements are not financial instruments); United States v. Howick, 263 F.3d 1056, 1067-69 (9th Cir. 2001), cert. denied, 535 U.S. 946 (2002) (stating that phony Federal Reserve notes are fictitious instruments).

123. See, e.g., In re Omega Envtl. Inc., 219 F.3d 984, 987 (9th Cir. 2000) (per curiam) (holding that a certificate of deposit is an instrument); see also In re Newman, 993 F.2d 90, 95 (5th Cir. 1993) (holding that an annuity contract is not an instrument because it is not transferred in the regular course of business); In re Commercial Money Ctr., Inc., 392 B.R. 814, 833-34 (B.A.P. 9th Cir. 2008) (holding that surety bonds are not instruments because they are not transferrable by delivery in the ordinary course of business and do not provide for the payment of any sum certain). 
Treasury set up HAMP by creating a model contract entitled, no doubt with the language of EESA in mind, the Commitment to Purchase Financial Instrument and Servicer Participation Agreement. ${ }^{124}$ Fannie Mae, as financial agent of the United States, was authorized to enter this contract with any loan servicer eligible to participate in the program. Under the contract, Fannie Mae pays loan servicers to modify mortgage contracts in favor of homeowners, using funds made available to Treasury under EESA. In addition, Fannie Mae channels money through the loan servicer to homeowners who stay current with HAMP-modified loans and investors whose contractual rights are modified.

The contract modification is embodied in a writing but it does not evidence a right to the payment of a monetary obligation. Instead, it evidences a right to the modification of mortgages held by others. Someone who possesses the Financial Instrument, whether Fannie Mae or a transferee, would have no right to obtain money from anyone. In addition, writings evidencing rights to loan modifications are not transferred by delivery in the ordinary course of business. Such rights may be assigned as part of a contract, but their value is not embodied in a piece of paper which is routinely transferred as a way of conveying value, as is the case for checks, securities, and other conventional financial instruments.

The other violation took place during the automaker bailout. In the fall of 2008 and the first half of 2009, Treasury used TARP funds to advance loans to GM and Chrysler, both of which ultimately entered bankruptcy and reemerged with stripped-down operations and modified capital structures. ${ }^{125}$ GM and Chrysler are not financial institutions but ordinary businesses, and hence to all appearances beyond the scope of Treasury's authority under EESA. Treasury noted that GM and Chrysler each owned a financial subsidiary, which advanced funds to car buyers, but Treasury could have made loans to

124. See Commitment To Purchase Financial Instrument AND SeRVICER PARTICIPATION AGREEMENT (2009), https://www.treasury.gov/ initiatives/financial-stability/TARP-Programs/housing/mha/Documents_

Contracts_Agreements/bankunited_Redacted.pdf.

125. See In re Chrysler LLC (Chrysler II), 576 F.3d 108, 121-22 (2d Cir. 2009), vacated, 592 F.3d 370 (2d Cir. 2010); In re Motors Liquidation Co. (Motors II), 430 B.R. 65, 91 (Bankr. S.D.N.Y. 2010), reh'g denied, 2010 WL 3565494 (S.D.N.Y. Sept. 10, 2010). 
those subsidiaries without also making loans to the holding companies. Treasury also argued that the automakers were interconnected with the financial institutions. ${ }^{126}$ If Chrysler collapsed, then Chrysler Financial would collapse as well-it would not have Chrysler customers to lend to-and the collapse of Chrysler Financial would reverberate throughout the financial system, exacerbating the liquidity crisis. ${ }^{127}$

As far as I am aware, the government never attempted to demonstrate that collapse of Chrysler Financial or GM Financial would have caused a systemic failure. By the time of the bankruptcies in the late spring of 2009 , the immediate threat to the financial system had been resolved. If the Secretary's say-so was entitled to deference, as one court concluded, ${ }^{128}$ then the restriction to financial institutions in the statute would have been meaningless, since all businesses are connected to the financial system. ${ }^{129}$ In bankruptcy, the government used its power as debtor-in-possession financer to manipulate payoffs, ensuring that lower-priority but politically connected groups like auto workers were paid more than secured creditors and equal-

priority unsecured creditors. While courts ultimately approved the bankruptcy outcomes (with some litigation pending ${ }^{130}$ ), scholars have persuasively argued that the wealth transfers that took place through the bankruptcy process violated bankruptcy law. ${ }^{131}$

\section{E. FDIC}

During the crisis, FDIC went well beyond its normal role of providing insurance to bank depositors. In October 2008, it created the Temporary Liquidity Guarantee Program (TLGP). ${ }^{132}$

126. Chrysler II, 576 F.3d at 121-22.

127. Id. at 122 n.14.

128. Motors II, 430 B.R. at 94.

129. In Chrysler II and Motors II, challenges to Treasury's authority were dismissed on grounds of standing. Chrysler II, 576 F.3d 108; Motors II, 430 B.R. 65 .

130. A\&D Auto Sales, Inc. v. United States, 748 F.3d 1142 (Fed. Cir. 2014).

131. See Douglas G. Baird, Lessons from the Automobile Reorganizations, 4 J. LEGAL ANALYSIS 271 (2012); Mark J. Roe \& David Skeel, Assessing the Chrysler Bankruptcy, 108 MICH. L. REV. 727 (2010).

132. See U.S. Gov't ACCOUNTABILITy OFFICE, FEDERAL DePosit InSURANCE ACT: REGUlators' USE OF SYSTEMIC RISK EXCEPTION RAISES MORAL HAZARD CONCERNS AND OPPORTUNITIES EXIST TO CLARIFY THE PROVISION 2 (2010), http://www.gao.gov/assets/310/303248.pdf [hereinafter FDIA REPORT]. 
The TLGP was composed of two pieces: a Debt Guarantee Program (DGP) and a Transaction Account Guarantee Program (TAGP). ${ }^{133}$ Under the DGP, banks paid a fee to the FDIC fund in return for guarantees of new unsecured debt. ${ }^{134}$ Under the TAGP, banks could pay for the extension of deposit insurance to non-interest bearing accounts greater than $\$ 250,000$, that is, beyond the then-existing limit of deposit insurance (which had been raised from $\$ 100,000$ on October $\left.3,2008^{135}\right){ }^{136}$ TAGP was designed to deter large depositors like businesses from withdrawing funds from demand deposit accounts, while DGP enabled banks to raise more funds if withdrawals nonetheless occurred. ${ }^{137}$ The programs were made available not only to insured banks, but to bank-holding companies and bank affiliates that are not entitled to ordinary FDIC deposit insurance.

FDIC claimed authority for TLGP under $\S 13(\mathrm{c})$ of the Federal Deposit Insurance Act. ${ }^{138}$ The law authorizes FDIC "to make loans to, to make deposits in, to purchase the assets or securities of, to assume the liabilities of, or to make contributions to, any insured depository institution" in order to prevent it from defaulting; to restore it to normal operation; or to prevent it from taking down other banks, "when severe financial conditions exist," if the collapse of those other banks would threaten the FDIC fund. ${ }^{139}$ Other provisions dictate that FDIC must satisfy "least-cost" requirements, meaning that it must use the least costly method of helping a bank, and should not benefit uninsured creditors, shareholders, and affiliates of the bank in question. ${ }^{140}$

The key provision in $\S 13$ (c) creates an exception in the case of systemic risk. If various procedural hurdles are satisfied, and Treasury (in consultation with the President) determines that compliance with the least-cost requirements "would have serious adverse effects on economic conditions or financial

133. Id. at $19-20$.

134. Id. at 19 .

135. Press Release, Fed. Deposit Ins. Corp., Emergency Economic Stabilization Act of 2008 Temporarily Increases Basic FDIC Insurance Coverage from $\$ 100,000$ to $\$ 250,000$ Per Depositor (Oct. 7, 2008), https://www.fdic.gov/ news/news/press/2008/pr08093.html.

136. FDIA REPORT, supra note 132, at 19.

137. For a more detailed description of the programs, see $i d$. at 19-23.

138. See id. at app. II.

139. 12 U.S.C. $\S 1823(\mathrm{c})(1)(\mathrm{A})-(\mathrm{C})(2012)$.

140. Id. § 1823(c)(4). 
stability," then FDIC "may take other action or provide assistance under this section . . . as necessary to avoid or mitigate such effects." ${ }^{\text {"14 }}$ The italicized language is key. The most natural reading is that FDIC may (1) take other action under this section; or (2) provide assistance under this section. The FDIC can use only the powers it has under the section-to lend, to buy assets, to monitor, and so on-but it can use them, when systemic risk exists, to help banks and counterparties who would otherwise be denied help because they do not have FDIC insurance.

FDIC's position, as summarized by the GAO, is that when the systemic risk exception is triggered, FDIC's power to "take other action or provide assistance under this section as necessary to avoid or mitigate such effects" permits it to engage in any action-whether or not listed in the statute-as long as the action would mitigate systemic risk. ${ }^{142}$ FDIC reads the language to create two powers: "to take other action" of any type, and "to provide assistance under this section." If systemic risk exists, FDIC may invoke its statutory powers ("provide assistance under this section") or-do anything.

This is a stretch. The interpretation renders the phrase "provide assistance under this section" meaningless because it is fully encompassed by "other action." The language "under this section" refers back to both "other action" and "provide assistance," confining the action/assistance powers to those that FDIC already possesses under the statute or closely related to them-the only purpose of the section being to eliminate the least-cost requirements when the entire banking system is at stake. FDIC's interpretation converts FDIC into a general LLR that can rescue any company, not just a bank. However, Congress saw FDIC as foremost a preserver of the deposit insurance fund and supervisor of banks, and in 1991 added language to FDIC's authorizing statute to encourage it to spend as little money rescuing banks as possible. ${ }^{143}$ If a systemic crisis occurs, FDIC may rescue a bank in the non-least-cost-way-for example, by paying off creditors who are not covered by deposit insurance, or keeping a bank temporarily alive when it is insolvent-when nonpayment of creditors or the bank's failure

141. Id. $\S 1823(\mathrm{c})(4)(\mathrm{G})$ (emphasis added).

142. FDIA REPORT, supra note 132 , at 50.

143. Id. at 5 . 
would threaten the system. By contrast, under the TLGP, FDIC offered insurance beyond the regular FDIC insurance program to banks that were not under threat of collapse and that were not determined to be systemically important, and to nonbanks as well. ${ }^{144}$

FDIC also violated the law through its participation in the public-private investment program, an initiative from Treasury that enabled private entities and Treasury to jointly buy toxic loans and toxic securities from banks. ${ }^{145}$ FDIC facilitated this program by insuring the debt issued by Public-Private Investment Funds (PPIF), which were supplied by equity capital from Treasury and private investors. PPIFs would buy undervalued mortgages from banks, and either hold them to maturity or sell them after their prices recovered. The debt, secured by the mortgages, would be paid off first, with the balance going to the investors, as usual. FDIC relied on the systemic-risk trigger in its statute. Under its interpretation, the PPIF guarantees certainly qualified as "other actions," and other actions that plausibility mitigate systemic risk. Under the more plausible interpretation of the statute, the PPIF guarantees were illegal because they were not issued to banks. They were issued to funds or trusts, which were effectively hedge funds, not depository institutions. ${ }^{146}$

\section{F. The Problem of Administrative Structure}

Divisions among agencies prevented a unified response to the financial crisis to an extent that has not been appreciated. Before the crisis, two major agencies stood ready to provide emergency liquidity support: the Fed and FDIC. As we have seen, the Fed was authorized to make emergency secured loans, both to banks and non-banks. ${ }^{147}$ FDIC was authorized to make emergency loans to-and also to engage in other transactions with, like buying assets from-banks alone. ${ }^{148}$ In addition, FDIC's authority was limited to addressing undercapitalized or

144. See id. at 50.

145. Press Release, U.S. Dep't of the Treasury, Public-Private Investment Program 1 (Mar. 23, 2009), http://www.treasury.gov/press-center/press -releases/Documents/ppip_whitepaper_032309.pdf.

146. For a discussion of the legal debate, see WALLACH, supra note 1 , at 152-53.

147. See 12 U.S.C. $\S 343(3)(B)(i)$ (2012).

148. See supra Part II.E. 
insolvent banks, while the Fed's authority-at least, by custom-was limited to helping solvent institutions.

Treasury had no standing rescue authority-putting aside the ESF, which was clearly not intended for financial-crisis rescue purposes. EESA placed $\$ 700$ billion at the disposal of Treasury once the crisis began, funds that Treasury was authorized to use to help any financial institution by buying assets, making loans, and acquiring equity. Even after Treasury received these funds, the Fed and FDIC continued to play extremely important roles in the rescue, as we have seen.

While all of the agencies were designed to play a role in rescuing the financial system, their roles-and hence their missions-differed. Sheila Bair, for example, saw her primary job as ensuring that the FDIC fund was not depleted, so that insured depositors would be protected. ${ }^{149}$ Bernanke, Geithner, and Paulson believed that she put the fund's solvency over the health of the financial system. Indeed, by insisting that the fund pay out only those with insurance, Bernanke and the others believed that Bair was putting the fund at greater risk because if the shadow banking system collapsed, depositors would run on banks, destroying the FDIC fund. They tried to persuade her to make the FDIC guarantee more broadly available. Although Bair eventually agreed, authorizing FDIC's participation in the TLGP and the PPIP, she did so only after delay and friction.

Bernanke saw the Fed as the ultimate LLR, but he also defined its role in narrower terms than he might have. The Fed traditionally earns financial returns through its operations, and every year turns over its "profits" (revenues minus operating expenses) to Treasury. As the financial crisis unfolded, Bernanke began to fear that those profits might be reduced to zero. ${ }^{150} \mathrm{He}$ believed that if the Fed turned over no money to Treasury - or lost money - the political repercussions would be severe. This explains why Bernanke frequently interpreted $\S 13(3)$ to mean that the Fed could lend only to solvent institutions, while $\S 13(3)$ is not so limited; and why Bernanke on several occasions obtained letters from Paulson that verified that a particular lending program might lose money. ${ }^{151}$ The letters

149. BAIR, supra note 66, at 2 .

150. BERNANKE, supra note 70 , at 204.

151. Id. at 205 . 
were not legally required, but would provide political cover in the case of a loss. Bernanke's concerns help explain why he refused to rescue Lehman-which he believed was insolventand why he told Paulson that it would be necessary to go to Congress for additional money.

Treasury is, by custom, the fiscal authority. With congressional authorization, it spends the government's money. That is why Paulson took the lead negotiating with Congress for EESA, and why EESA authorized spending through Treasury. And this is why Bernanke asked Paulson to write letters supporting several Fed programs that could have produced losses for Treasury. Treasury was allowed, through EESA, to make risky investments and buy risky assets, and thus was permitted to take losses.

As a non-independent agency under the direct supervision of the President, Treasury is also a more "political" agency than the Fed and FDIC-that is, more sensitive to popular opinion as channeled through the Presidency than the Fed and FDIC, both of whose major concern is to retain their legitimacy with Congress. This, too, was reflected in Treasury's actions. Paulson (and later Geithner) regularly consulted with the President and Congress. Paulson, stung by the negative reaction to the Bear rescue, and philosophically opposed to intervening in markets, was initially more cautious about bailouts than the Fed. ${ }^{152}$ Geithner, once in office, found himself under pressure from Congress and the President's supporters to use TARP funds on foreclosure relief, despite his doubts about its effectiveness. ${ }^{153}$ By contrast, the Fed and FDIC showed little interest in this issue. ${ }^{154}$

While the Fed, Treasury, and FDIC were the main players, they needed to contend with numerous other agencies with authority over other pieces of the financial system. The Office of the Comptroller of the Currency (OCC) and the Office of Thrift Supervision (OTS) were the primary regulators of the national banks and the federal S\&Ls. These agencies lacked LLR authority but nonetheless tried to protect the institutions they regulated from shut-downs, and in general acted as nuisances.

152. See supra notes 104-05.

153. GEITHNER, supra note 86, at 209-10.

154. In her memoir, Bair expressed concern about homeowners, but there was little that the FDIC could do for them. BAIR, supra note 66 , at 49-53, 128. 
The SEC used its emergency powers to implement a temporary short-sale ban-apparently, at the behest of the Fed and Treasury-and otherwise did little of value. ${ }^{155}$ The Federal Housing Finance Agency (FHFA) operated the conservatorships of Fannie Mae and Freddie Mac; Geithner would later complain that it obstructed efforts to revive the mortgage market. ${ }^{156}$

She feared that Citigroup would choke on Wachovia, exposing FDIC's insurance fund to massive liabilities. Geithner was infuriated by Bair's stance. ${ }^{157}$ He believed that the government's credibility was at stake, but the real source of disagreement appears to be that Geithner wanted to help Citigroup, which would have benefited from Wachovia's deposit base. ${ }^{158}$

This episode can be read in two ways: as a good-faith disagreement about the proper crisis response, and as a clash between bureaucratic missions. Under the former interpretation, the agencies disagreed about timing and tactics: whether to provide assistance to Citigroup by favoring it over Wells Fargo, even though Wells Fargo offered the better deal, or to provide assistance to Citigroup later through a direct infusion of funds (as happened). Bair believed that the latter approach was more transparent and fair, while Geithner believed that the press of events did not allow for it. As a bureaucratic clash, the dispute can be seen as one in which each agency favored its turf. FDIC sought to preserve the bank insurance fund; Geithner sought to protect a major bank with which the FRBNY had a close relationship.

Another dispute occurred over Lehman. Among the principals, Geithner was the most anxious to save Lehman-and, in general, the most aggressive about bailing out firms. Paulson was most reluctant. Bernanke was in the middle. An explanation for this division was that Paulson was the most politically accountable-and the public mood at that time was decisively

155. The SEC was also asked to relax mark-to-market accounting standards but refrained from doing so, instead issuing an ambiguously worded statement recognizing that those standards allow firms to abandon marks during liquidity crises. See generally Christian Laux \& Christian Leuz, Did Fair-Value Accounting Contribute to the Financial Crisis?, 24 J. ECON. PERSP. 93 (2010).

156. GEITHNER, supra note 86, at 174-76; see also W. Scott Frame et al., The Rescue of Fannie Mae and Freddie Mac, 29 J. ECON. PERSP. 25, 47-49 (2015).

157. GEITHNER, supra note 86 , at 217.

158. See BAIR, supra note 66, at 88; GEITHNER, supra note 86, at 217-19. 
opposed to bailouts. Bernanke also worried about the public's and Congress's suspicion of the Fed and sought to avoid a transaction in which the Fed lost money. Geithner, while also a Fed employee, was not as central a figure and was freer to act on his judgment as to what was best for the financial system.

All that said, the initial reactions to the bailouts showed more consensus than disagreement among the three LLR agencies. This probably reflected their relative political insulation. Even Paulson was protected by Bush's lame duck status. By contrast, Congress could not avoid politics. Members of Congress, unlike President Bush, faced reelection campaigns in November 2008. By the time of EESA, much of the public had come around to bailouts, but intense dissent remained, and EESA was initially voted down in the House. ${ }^{159}$ It was eventually passed only after $\$ 150$ billion of pork had been added to the Senate version of the bill. ${ }^{160}$ The many payoffs-such as the repeal of an excise tax on toy arrows ${ }^{161}$-were transparent interest-group transfers that were unrelated to the policy questions raised by the law. The substantive provisions of EESA reflected the influence of the finance industry. Mian et al. find a statistically significant correlation between campaign contributions from Wall Street and an elected official's vote in favor of EESA. $^{162}$

After EESA was enacted, politically connected firmsdefined in various ways, including firms with directors who worked for a banking regulator or Treasury-were more likely to receive TARP funds than other firms. ${ }^{163}$ There is also evidence that investors in firms with political connections to Geithner expected those firms to benefit when Geithner was appointed Treasury Secretary. ${ }^{164}$

159. PAULSON, supra note 98 , at 319-20.

160. See Atif Mian et al., The Political Economy of the U.S. Mortgage Default Crisis, 100 AM. ECON. REV. 1967, 1972 (2010) ("The bill also included up to $\$ 150$ billion of unrelated tax breaks for individuals and businesses . . ..").

161. Breakdown of the Final Bailout Bill, WASH. Post (Sept. 28, 2008), http://www.washingtonpost.com/wp-dyn/content/article/2008/09/28/ AR2008092800900.html.

162. Mian et al., supra note 20, at 18; see also Michael Dorsch, Bailout for Sale? The Vote To Save Wall Street, 155 PUB. CHOICE 211 (2013).

163. See Ran Duchin \& Denis Sosyura, The Politics of Government Investment, 106 J. FIN. ECON. 24 (2012).

164. Daron Acemoglu et al., The Value of Connections in Turbulent Times: Evidence from the United States, 121 J. FIN. ECON. 368, 368 (2016) 
The political economy of the crisis response is too complex to allow for simple conclusions and requires more study. But this much seems to be clear: Congress was more responsive to public opinion than the agencies, and Treasury was more responsive to public opinion than the Fed and FDIC. Congress had a less sophisticated understanding of the crisis, and Congress, as always, was both slower and more transparent than the agencies. But the influence of interest-group pressures is difficult to untangle: was Congress more heavily influenced by them than the agencies were, or not? A tentative view is that the agencies reacted more quickly and more as technocratic experts than Congress did, but they were also influenced by narrow bureaucratic missions as well as complex interest-group pressures.

\section{G. Conclusion: Gaps in the Rescue Agencies' Authority}

The crisis response was hampered by gaps in the government's powers. While EESA closed some of these gaps, the involvement of Congress in the midst of a crisis created problems of its own. There was not enough time for members of Congress to educate themselves about the crisis and to deliberate about it. Election-year politics also interfered with deliberation. Experts outside the government, whose testimony would have normally been sought, were excluded from participation by Democrats who, according to a pair of authors, wanted to ensure that the public would associate the crisis response with the Bush administration. ${ }^{165}$ Congress was little more than a rubber stamp.

In sum, the agencies were hampered by their lack of authority to:

("[F]inancial firms with a connection to Geithner experienced a cumulative abnormal return-relative to other financial sector firms-of about 6\%.").

165. See Calomiris \& Khan, supra note 111, at 72 ("[Democrats] did not want independent testimony to put them 'on the spot.' They did not want to have to create or politically 'own' new ideas about assisting banks. The path of least political resistance was to let Secretary Paulson take the lead and the responsibility."). 
- Buy assets, including equity; ${ }^{166}$

- Make unsecured loans to non-bank financial institutions;

- Control non-bank financial institutions to which the Fed made loans, in order to force them to pay off counterparties, lend money, and so on;

- Wind up insolvent non-bank financial institutions, including the lack of authority to lend to them or counterparties in order to ensure an orderly liquidation;

- Force non-bank financial institutions to raise capital; and

- Dictate terms of transactions, control the behavior of firms (for example, forcing them to lend), or acquire them where necessary.

In the absence of these authorities, the agencies improvised, but in ways that were far from ideal. First, the agencies used veiled threats to force financial institutions to act in needed ways. Second, the agencies "regulated by deal" ${ }^{167}$ —effectively bribing financial institutions to act as desired. As an illustration of both these points, in order to persuade banks to participate in the Capital Purchase Program (CPP), Treasury offered favorable terms and issued a veiled threat that things would go poorly for banks that did not participate. ${ }^{168}$ Third, the agencies, in a number of instances, simply violated the law-as the Fed did when it acquired equity in AIG and controlled its operations. Fourth, the agencies ultimately demanded a law from Congress, which caused delay and numerous other problems. Further exacerbating all these problems, the major agenciesTreasury, the Fed, and FDIC-failed to coordinate on a number of occasions because of conflicting bureaucratic missions as well as good-faith disagreements.

166. Often called the "market-maker of last resort" function. See, e.g., Paul Tucker, The Lender of Last Resort and Modern Central Banking: Principles and Reconstruction 28-32 (Bank for Int'l Settlement, Paper No. 79, 2014). For an overview of the debate, see Colleen Baker, The Federal Reserve as Last Resort, 46 U. MICH. J.L. REFORM 69 (2012). For a model in which a central bank can address a liquidity shock by purchasing equity, in this way improving liquidity, see Nobuhiro Kiyotaki \& John Moore, Liquidity, Business Cycles, and Monetary Policy (Nat'l Bureau of Econ. Research, Working Paper No. 17934, 2012), http://www.nber.org/papers/w17934.pdf.

167. Steven M. Davidoff \& David Zaring, Regulation by Deal: The Government's Response to the Financial Crisis, 61 ADMIN. L. REV. 463 (2009).

168. See WESSEL, supra note 31 , at 237-40. 


\section{REFORM}

\section{A. Substantive Authorities}

When a tornado, hurricane, or earthquake strikes, the Federal Emergency Management Agency (FEMA) sends personnel, resources, and money to the affected area, while the police or national guard uses emergency authority to keep order. The government is not required to ask Congress for assistance; legal authority to respond to the emergency in all ways necessary is already in place. This simple model should guide the design of what I will call the Financial Crisis Response Authority (FCRA).

The FCRA, because of its vast powers, should be permitted to act only after a financial crisis has begun. The law should, as now, provide that the FCRA's authorities are triggered upon agreement by a supermajority of top economic officials, including the President. These officials should also release a statement that describes objective indicators of crisis, such as a collapse of lending or other signs of loss of confidence.

Once the crisis begins, the FCRA would be able to draw on an unlimited credit line from Treasury or on a fund supplied from taxes on all financial institutions, or (best of all) both. ${ }^{169}$ An unlimited credit line would follow the model of the Fed, which can extend credit on its own account, enabling the FCRA to borrow enough money to fund its rescue activities, whatever magnitude the crisis. A fund would follow the model of the FDIC, which relies on a fund financed by assessments from banks with FDIC insurance. Each approach has different advantages. The problem with a fund is that it could run out of money before the crisis has been resolved. Congress would need to replenish it, creating the risk of delay or failure to act, which would greatly worsen the crisis. In contrast, the FCRA could draw on an unlimited credit line indefinitely.

However, a fund might be more politically appealing because it is self-financing. When financial institutions receive payouts from a fund financed by their own assessments, there is no sense in which they are being "bailed out" by the taxpay-

169. Jeffrey Gordon and Christopher Muller persuasively make the case for such a fund. See Jeffrey N. Gordon \& Christopher Muller, Confronting Financial Crisis; Dodd-Frank's Dangers and the Case for a Systemic Emergency Insurance Fund, 28 YALE J. REG. 151 (2011). 
er. This is a particular advantage if firms are insolvent, and not merely illiquid. During the crisis, the FDIC took much less political heat than the Fed, probably for this reason. A good case could be made for a limited fund, which could be supplemented by lending authority, and perhaps a requirement that the Fed seek approval from Congress as well.

However it is funded, the FCRA could use its resources to buy financial assets, including notes, loans, bonds, and stock; to make secured and unsecured loans; to purchase and take control of financial institutions; and to seize financial institutions under the power of eminent domain with just compensation determined by a judicial valuation at a later date. The FCRA would also enjoy a separate regulatory or supervisory power, which would enable it to order financial institutions to raise capital, to shut down operations, to sell assets, and to borrow money; it would also be given the power to ban or regulate market transactions, like short sales. ${ }^{170}$

The recent financial crisis shows why all these powers are necessary and the conventional Bagehot approach is inadequate. Because of the fear of stigma, even liquidity-constrained financial institutions will be inclined to delay before borrowing from emergency credit facilities. The FCRA needs the authority to force those firms to borrow, and also to force healthy firms to borrow at the same time in order to prevent the market from picking off the weakest firm. Moreover, the crisis showed that when financial institutions accept emergency loans, they have strong incentives to hoard cash, when the system as a whole benefits only if they lend into the market a portion of the money they borrow. For this reason, the FCRA needs the authority to order firms to enter financial transactions. Finally, the crisis showed that financial institutions that should be given emergency money may not be able to offer collateral for a loan, and it may be very difficult to value the collateral in any event. The FCRA needs the authority to make capital injections, issue unsecured and partially secured loans, and buy assets.

170. During the financial crisis, the SEC, apparently under pressure from the Fed, briefly banned short sales on financial stocks. At the time, some analysts believed that short-selling artificially suppressed the equity value of banks, creating concerns about their insolvency that could create a downward spiral. The academic consensus, however, is that bans on short sales, here and abroad, caused harm. See, e.g., Ekkehart Boehmer et al., Shackling Short Sellers: The 2008 Shorting Ban, 26 REV. FIN. STUD. 1363 (2013). 
Vast powers create opportunities for abuse; the FCRA cannot be given unlimited power. Judicial review during a crisis is impractical, as the 2007-08 crisis showed. People negatively affected by the government's actions could not persuade courts to intervene. ${ }^{171}$ Judges are unwilling to interfere with emergency actions by expert agencies. Courts move too slowly and lack expertise. One court denied relief even after the crisis, explaining that if it did award damages to the claimants, then government officials would refuse to take justified risks during the next crisis. ${ }^{172}$ However, this view, if taken to its logical extreme, would eliminate any constraint on the government. A robust legal regime to correct abuses after the crisis can be put into place. As noted, where the FCRA uses force to acquire firms and other assets, the owners will be able to sue the government for damages based on a proper valuation that uses fundamental rather than crisis-driven asset values. In addition, where the FCRA uses it regulatory and supervisory authorities to order firms to shed assets and make loans, the firms will be entitled to sue after the crisis and receive a remedy if they can show that the FCRA's actions were unreasonable. The usual postcrisis analyses by independent government agencies with the power to compel testimony and discover documents from the FCRA will facilitate the litigation by collecting facts and making them publicly available.

\section{B. ADMINISTRATIVE ORGANIZATION}

The complex division of responsibility between financial regulatory agencies hampered the crisis response. How should the FCRA be designed to do better? It is tempting to argue that all powers should be handed to it, eliminating at a stroke the problem of interagency rivalries. However, it is doubtful that such a powerful agency would be politically acceptable, while existing agencies are too deeply entrenched in the government's institutional structure to be swept aside. The Dodd-Frank Act

171. See, e.g., Marcel Kahan \& Edward Rock, How To Prevent Hard Cases from Making Bad Law: Bear Stearns, Delaware, and the Strategic Use of Comity, 58 EMORY L.J. 713, 714-15 (2009).

172. Starr Int'l Co. v. Fed. Reserve Bank of N.Y., 906 F. Supp. 2d 202, 247 (S.D.N.Y. 2012) (referencing "distinct areas of doctrine" in which "tort liability for governmental actors is narrowly limited or precluded altogether, in order to give such actors the latitude and discretion to do their jobs effectively, including when circumstances are pressing and there is limited time to act"). Disclosure: I worked on this case for the plaintiffs. 
eliminated the Office of Thrift Supervision, but addressed the entrenched status of the other agencies by layering a coordinating body, the Financial Stability Oversight Council (FSOC), above them. ${ }^{173}$ The FSOC identifies risks in the financial system, identifies systemically risky institutions, and orders the breakup of too-big-to-fail entities, but it does not enjoy any rescue authority aside from a coordinating function.

This seems inadequate, but it is not clear what the alternative is. The problem with the existing regulatory structure, revealed by the financial crisis, is that the different agencies develop constituencies that they try to protect: for the OCC, big New York banks; for the OTS, thrifts; for FDIC, regular banks; for the Fed, big Wall Street financial institutions. FEMA or the National Guard do not favor constituencies, but rather see their mission as protecting people and restoring order. ${ }^{174}$ It is possible to think that a financial agency could be given a similar purely ex post mission, detached from ex ante regulatory responsibilities that might cause it to favor some entities over others. But the connection between ex ante regulation and ex post response seems necessary to ensure that agencies possess enough information and expertise about the financial system to be able to act wisely during a crisis.

If we use history as our guide, the Fed seems to be the agency that shows the least favoritism and the most consideration for the general public rather than for specific groups. Because of their power over the money supply, central banks are in a better position than other agencies to address a financial crisis. This role has been understood for a long time and is central to the mission and self-conception of central banks. The Fed already has the broadest powers and the greatest level of sophistication among all the financial agencies. While practical and institutional constraints cannot be wished away, Congress should gradually transfer additional powers to the Fed-such as the power to buy assets, make unsecured loans, and acquire

173. Dodd-Frank Wall Street Reform and Consumer Protection Act, Pub. L. No. 111-203, 124 Stat. 1376 (2010).

174. This is not to say that these institutions perform blamelessly. FEMA, in particular, has been subject to criticism for decades, and has been reorganized numerous times. See Henry B. Hogue \& KeITH BeA, Cong. ReSEARCH SERV., RL33369, FEDERAL EMERGENCY MANAGEMENT AND HOMELAND SECURITY ORGANIZATION: HistoriCAL DEVELOPMENTS AND LEGISLATIVE OPTIONS (2006). 
equity-while removing LLR powers from other agencies, to the extent politically feasible.

\section{DODD-FRANK}

In the Dodd-Frank Act, Congress created a much-needed resolution authority for non-bank financial firms. It named it the Orderly Liquidation Authority (OLA) and placed it under the control of FDIC. ${ }^{175}$ But Congress perversely reduced the power of the LLR in three ways. First, it amended $\S 13(3)$ of the Federal Reserve Act to require that emergency loans take place through a "program or facility with broad-based eligibility."176 This provision was intended to ban bailouts similar to those of Bear and AIG, which were directed to a single company rather than a group of companies. By contrast, the many credit facilities were open to any company that satisfied certain criteria. Facilities like those would remain lawful under the amendment.

Second, Congress blocked Treasury from using the Exchange Stabilization Fund to finance "any future guaranty programs for the United States money market mutual fund industry." ${ }^{177}$ This was intended to prevent a repeat of the Temporary Guarantee Program, which helped end the run of money market mutual funds.

Third, Congress put constraints on FDIC's power to offer system-wide guarantees, mainly by erecting procedural hurdles and stipulating that the guarantee cannot benefit insolvent institutions. ${ }^{178}$ Congress was apparently reacting to FDIC's Temporary Liquidity Guarantee Program, which, as we saw, may have violated FDIC's legal authority.

By placing additional restrictions on the Fed and the other agencies and placing the OLA outside the Fed, Congress weakened the power of the government to address a financial crisis. ${ }^{179}$ How much it weakened the government is hard to say. If

175. 12 U.S.C. $\$ \$ 5381-5394$ (2012).

176. See id. $\S 343$. In 2015, the Fed adopted regulations implementing the law. See David Harrison, Fed Adopts Dodd-Frank Bailout Limits, WALL ST. J. (Nov. 30, 2015), http://www.wsj.com/articles/fed-set-to-adopt-final-emergency -lending-rule-1448889633.

177. 12 U.S.C. $\$ 5236(\mathrm{~b})(2012)$.

178. Id. $\S \S 5611-5612$.

179. Interestingly, there is some evidence that the customized rescues created moral hazard while the non-customized forms of liquidity support did not. 
the last crisis is a guide, agencies will be able to coordinate in the major crisis response, and they will read the new restrictions narrowly in order to evade them. But Congress missed an opportunity to provide necessary additional authority to the LLR and reduce its coordination costs.

\section{CONCLUSION}

The financial crisis exposed significant gaps in the LLR's authority. While Congress filled one gap with the OLA, it perversely widened the others. It should have enhanced the powers of the LLR and gathered as many of those powers as possible into the hands of the Fed, subject to a strong procedural trigger that requires consensus among top economic officials and the President that a financial crisis has begun. The reason is simple. The LLR powers available to the Fed and other agencies reflected a simpler world in which the banking system was the primary source of short-term liabilities, so that the FDIC fund plus the Fed's residual lending powers sufficed to stop a crisis, even to prevent a crisis from starting. A new system that extends the LLR to the shadow banking system is needed.

Congress did not create such an LLR for numerousmostly political-reasons, including distrust of the Fed and popular resentment at the bailouts of Wall Street firms. The most important policy reason for restricting the LLR is the theory that a generous LLR encourages financial institutions to behave recklessly - a theory that was adopted in Dodd-Frank itself. ${ }^{180}$ Economists disagree about whether moral hazard is a significant concern, and I will not address this topic here. ${ }^{181}$ The minimal point is that moral hazard is not a justification for depriving the LLR of the powers that it needs to rescue the financial system. The necessity of an LLR is (within mainstream economic and political circles) uncontested. And if an LLR is necessary, then it should be supplied with the powers that it needs to function. Moral hazard justifies ex ante regulation

See Yacine Aït-Sahalia et al., Market Response to Policy Initiatives During the Global Financial Crisis, 87 J. INT'L ECON. 162, 176 (2012). However, it does not seem to me that the evidence is strong enough to justify depriving the Fed of this power.

180. The preamble claims that the Dodd-Frank Act will end bailouts. DoddFrank Wall Street Reform and Consumer Protection Act, Pub. L. No. 111-203, 124 Stat. 1376, 1376 (2010).

181. See supra note 35 . 
such as capital requirements, which are independent of the LLR's power, and (conceivably) requirements that the LLR penalize the firms that it rescues-for example, with high interest rates, as in the original Bagehot formulation. Both ex ante regulation and ex post penalizing are consistent with a powerful and robust LLR.

As an analogy, imagine that a town is plagued by residential fires, caused by the carelessness of homeowners who do not install smoke detectors and store flammable materials in their basements. The town could sensibly address this problem by enacting a fire code that it enforces with inspections. It could also address this problem by directing the fire department to replace hoses with squirt guns and tanker trucks with horsedrawn carriages. The second approach would certainly address moral hazard; residents, fearful that the fire department will not save their houses, would be more careful. But not all fires are caused by carelessness, and not all careless fires should be allowed to burn, since, by a process similar to financial contagion, fires may spread from house to house. The town does better with the fire code along with a modern fire department. And so with the LLR.

Expanding the power of the LLR is urgent because every financial crisis is different; the next one may not look like the last. Reacting to the most recent financial crisis, regulators today focus on mortgage underwriting, the repo market, and toobig-to-fail institutions. But a crisis could emerge in the student debt market, margin lending used for equity purchases if the stock market collapses, clearinghouses, or anywhere else. It could spread through small institutions rather than big ones. It is in the nature of financial systems that money will flee more highly regulated areas and seek out assets and transactions that regulators overlook or leave alone. To fight the next war rather than the last one, the LLR needs very broad authority, essentially over the entire financial system.

Numerous scholars have argued that the Fed and Treasury violated the rule of law during the financial crisis, and many of them also argue that the Fed needs to be stripped of powers so that it cannot violate the rule of law again. ${ }^{182}$ On inspection, it

182. See Samples, supra note 109; Lawrence H. White, The Federal Reserve and the Rule of Law, CATO INST. (Sept. 12, 2013), https://www.cato.org/ publications/testimony/federal-reserve-rule-law; Todd Zywicki, The Auto Bailout and the Rule of Law, NAT'L AFF., Spring 2011, http://www 
becomes clear that while the authors believe (in most cases, correctly) that the Fed violated the law during the crisis, their main complaint is that Congress has given the Fed too much discretionary power, which enables it to act arbitrarily. However, the constitutional limitations on delegation of power to agencies-embodied in the "nondelegation doctrine"-are effectively nil. The requirement that the LLR use its powers to unfreeze the financial system ${ }^{183}$ would supply the intelligible principle required by the "nondelegation doctrine" under recent precedents. ${ }^{184}$

A more serious version of this criticism, emphasized by Paul Tucker, is that, as a matter of political economy (as opposed to legal principles), an unconstrained central bank is both undesirable and unsustainable. ${ }^{185}$ Undesirable because we live in a democracy, and an independent agency with vast powers may act against the will of the people; and unsustainable because for just that reason, the agency will be regarded with suspicion and ultimately subject to constraints. ${ }^{186}$ Tucker advocates two types of constraints: procedural and substantive. The procedural constraints include reporting requirements, triggering rules that require the agreement of top officials, and the like. Few people would disagree with such requirements, which are mostly in place. As a substantive constraint, he argues that the LLR should never be allowed to lend to insolvent firms because such loans put at risk funds that go to Treasury, and hence they raise "fiscal" issues that are the province of Congress and the people.

Tucker's worries are well grounded. The restrictions on the LLR in the Dodd-Frank Act, along with routine threats by Congress to impose further restrictions on the Fed, reflect just those worries. The problem with his argument is that, as we saw during the financial crisis, lending to insolvent firms-or

.nationalaffairs.com/doclib/20110317_Zywicki.pdf; $c f$. Thomas W. Merrill \& Margaret L. Merrill, Dodd-Frank Orderly Liquidation Authority: Too Big for the Constitution?, 163 U. PENN. L. REV. 165 (2014) (arguing that the OLA is unconstitutional).

183. A similar principle can be found in EESA.

184. See Whitman v. Am. Trucking Ass'ns, Inc., 531 U.S. 457 (2001).

185. See Tucker, supra note 166, at 37 .

186. On Congressional efforts to rein in the Fed by requiring it to submit to audits and other requirements, see Sheila Tschinkel, Congress Auditing the Federal Reserve Is a Truly Frightening Idea, QUARTZ (Mar. 13, 2015), http://qz .com/362155/congress-auditing-the-federal-reserve-is-a-truly-frightening-idea. 
firms that are likely to be insolvent-may well be a sensible approach to a crisis. Many such firms often have counterparties that are solvent, and lending to insolvent firms, enabling them to pay their counterparties, may be a more efficient way of helping the counterparties than lending to them directly.

While the idea that the LLR should not invade the fiscal province of the legislature has a long history, going back to Bagehot and beyond, it is time to retire it. The fiscal-versusmonetary distinction is illusory during a financial crisis. The LLR can value most collateral only with difficulty, with the valuation depending on whether or not the crisis conditions will ameliorate in the near future. As a result, the LLR's collateral valuations are based in part on the LLR's own prediction about the effectiveness of its current and future actions, giving it a huge amount of effective discretion even under the strict Bagehot approach. Moreover, if the LLR acts weakly rather than aggressively, and fails to resolve the crisis, the negative fiscal consequences-lower tax receipts, higher transfer paymentswould vastly exceed losses on loans made to insolvent firms. And if the question is popular legitimacy, the fiscal-versusmonetary distinction will be lost on the public.

The LLR will be able to survive in a democracy, regardless of how powerful and independent it is, as long as the public believes that it serves the public interest. Depriving it of the powers it needs will not advance that goal. 
Copyright of Minnesota Law Review is the property of Minnesota Law Review and its content may not be copied or emailed to multiple sites or posted to a listserv without the copyright holder's express written permission. However, users may print, download, or email articles for individual use. 